\title{
Notes on some sertulariid hydroids (Cnidaria: Hydrozoa) from the tropical western Pacific, with descriptions of nine new species
}

\author{
Horia R. GALEA \\ Hydrozoan Research Laboratory, 405 Chemin des Gatiers, 83170 Tourves, France. \\ E-mail: horia.galea@gmail.com \\ urn:Isid:zoobank.org:author:DE5AC672-0243-46F2-A910-AFF4E91A4C5D
}

\begin{abstract}
Forty-three species of sertulariid hydroids (Cnidaria: Hydrozoa: Sertulariidae), collected from the tropical western Pacific (Taiwan, Philippines, New Caledonia, French Polynesia, Vanuatu, Fiji, Tonga, Solomon Islands) during various expeditions of the French Tropical Deep-Sea Benthos program, are discussed. Of these, nine are new to science: Gonaxia nova sp. nov., G. plumularioides sp. nov., Sertularella folliformis sp. nov., Se. plicata sp. nov., Se. pseudocatena sp. nov., Se splendida sp. nov., Se. tronconica sp. nov., Se. tubulosa sp. nov., and Symplectoscyphus paucicatillus sp. nov. The subspecies Symplectoscyphus johnstoni (Gray, 1843) tropicus Vervoort, 1993 is raised to species but, in order to avoid the secondary homonymy with Sy. tropicus (Hartlaub, 1901), the replacement name, Sy. fasciculatus nom. nov., is introduced. The male and female gonothecae of Diphasia cristata Billard, 1920, the male gonothecae of Gonaxia elegans Vervoort, 1993, as well as the female gonothecae of Salacia macer Vervoort \& Watson, 2003, are described for the first time. Additional notes on the morphology of several other species are provided. All taxa are illustrated, in most cases using figures drawn at the same scale, so as to highlight the differences between related species.
\end{abstract}

Key words. Deep water, new species, thecate hydroids, Sertulariidae.

Galea H.R. 2016. Notes on some sertulariid hydroids (Cnidaria: Hydrozoa) from the tropical western Pacific, with descriptions of nine new species. European Journal of Taxonomy 218: 1-52. http://dx.doi.org/10.5852/ejt.2016.218

\section{Introduction}

The present report is a continuation of an earlier study dealing with some new sertulariid and syntheciid hydroids (Galea 2015a), and completes a series of previous reports dealing with members of the families Sertulariidae Lamouroux, 1812 (Vervoort 1993), Halopterididae Millard, 1962 (Ansín Agís et al. 2009), Lafoeidae Hincks, 1868 (specifically, the genus Acryptolaria Norman, 1875) (Peña Cantero \& Vervoort 2010), and Kirchenpaueriidae Stechow, 1921 (Ansín Agís et al. 2014) from the tropical western Pacific, obtained during numerous expeditions undertaken conjointly by the Institut de Recherche pour le Développement (IRD, formerly ORSTOM) and the Muséum national d'Histoire naturelle (MNHN) of Paris (Bouchet et al. 2008).

The sertulariid hydroids dealt with herein belong to the following ten genera: Caminothujaria von Campenhausen, 1896, Diphasia L. Agassiz, 1862, Dynamena Lamouroux, 1812, Geminella Billard, 1925b, Gonaxia Vervoort, 1993, Idiellana Cotton \& Godfrey, 1942, Salacia Lamouroux, 1816, 
Sertularella Gray, 1848, Sertularia Linnaeus, 1758 and Symplectoscyphus Marktanner-Turneretscher, 1890. Although most species have already been dealt with by Vervoort (1993), additional notes on them are provided, along with new data on the morphology of other taxa, including descriptions of nine new hydroids.

\section{Material and methods}

The methods of study were described in detail by Galea $(2007,2008)$. The list of stations is given in Table 1. Station numbers, as indicated in the text, are preceded by a two-letter prefix referring to the sampling gear used to secure the material, either a Charcot dredge (CC), a beam trawl (CP), a rockybottom dredge (DR) or a Warrén dredge (DW). The material is deposited in the collections of MNHN.

The species dealt with herein are listed according to their morphological similarities, notably the shape of their hydrothecae. Most figures, representing portions of colonies, hydro- and gonothecae, are drawn to the same scale and grouped onto the same plates, so as to facilitate comparisons between related species.

\section{Results}

Phylum Cnidaria Verrill, 1865

Class Hydrozoa Owen, 1843

Subclass Hydroidolina Collins \& Marques, 2004

Order Leptothecata Cornelius, 1992

Family Sertulariidae Lamouroux, 1812

Genus Caminothujaria von Campenhausen, 1896

Caminothujaria molukkana von Campenhausen, 1896

Fig. 1A-B

Caminothujaria molukkana von Campenhausen, 1896: 103.

Caminothujaria molukkana - Schuchert 2015: 338, fig. 12.

\section{Material examined}

MUSORSTOM 3: Stn. DR117, numerous sterile fragments from an originally large colony (size undeterminable) (MNHN-IK-2012-16500); Stn. CP121, a $2.3 \mathrm{~cm}$ high, sterile colony (MNHNIK-2012-16501); Stn. DR126, an originally $11.5 \mathrm{~cm}$ high colony, now broken into two parts, one gonotheca (MNHN-IK-2012-16502).

MUSORSTOM 8: Stn. CP1001, several stems and fragments up to $5.3 \mathrm{~cm}$ high, all sterile (MNHNIK-2012-16503); Stn. DW1021, numerous sterile stems and fragments, 3-10.5 cm high, all sterile (MNHN-IK-2012-16504); Stn. CP1104, an originally large but sterile colony, now fragmented, largest fragment ca $8 \mathrm{~cm}$ high (MNHN-IK-2012-16505).

BORDAU 2: Stn. CP1582, ca 4 cm high, fertile colony composed of three stems (MNHN-IK-2012-16506).

SALOMON 1: Stn. DW1756, three sterile stems 2.5-5 cm high (MNHN-IK-2012-16507); Stn. DW1767, a ca $12 \mathrm{~cm}$ high, sterile colony (MNHN-IK-2012-16508).

\section{Remarks}

A list of synonyms is provided by Schuchert (2015) and, for a redescription, see Hirohito (1995). 
GALEA H.R., Sertulariid hydroids from the tropical western Pacific

Table 1. List of stations.

\begin{tabular}{|c|c|c|c|c|c|}
\hline Campaign & Station & Date & Depth (m) & Latitude & Longitude \\
\hline \multirow[t]{3}{*}{ MUSORSTOM 3} & $\begin{array}{l}\text { DR117 } \\
\text { CP121 }\end{array}$ & $\begin{array}{l}3 \text { Jun. } 1985 \\
3 \text { Jun. } 1985\end{array}$ & $\begin{array}{l}92-97 \\
73-84\end{array}$ & $\begin{array}{l}12^{\circ} 31^{\prime} \mathrm{S} \\
12^{\circ} 08^{\prime} \mathrm{S}\end{array}$ & $\begin{array}{l}120^{\circ} 39^{\prime} \mathrm{E} \\
121^{\circ} 17^{\prime} \mathrm{E}\end{array}$ \\
\hline & DR126 & 4 Jun. 1985 & 266 & $11^{\circ} 49^{\prime} \mathrm{S}$ & $121^{\circ} 22^{\prime} \mathrm{E}$ \\
\hline & CP134 & 5 Jun. 1985 & $92-95$ & $12^{\circ} 01^{\prime} \mathrm{S}$ & $121^{\circ} 57^{\prime} \mathrm{E}$ \\
\hline \multirow[t]{6}{*}{ BIOCAL } & $\mathrm{CP} 34$ & 29 Aug. 1985 & 710 & $23^{\circ} 11.88^{\prime} \mathrm{S}$ & $167^{\circ} 11.30^{\prime} \mathrm{E}$ \\
\hline & DW37 & 30 Aug. 1985 & 350 & $22^{\circ} 59.99^{\prime} \mathrm{S}$ & $167^{\circ} 15.65^{\prime} \mathrm{E}$ \\
\hline & DW38 & 30 Aug. 1985 & 360 & $22^{\circ} 59.74^{\prime} \mathrm{S}$ & $167^{\circ} 15.31^{\prime} \mathrm{E}$ \\
\hline & DW66 & 3 Sep. 1985 & $505-515$ & $24^{\circ} 55.43^{\prime} \mathrm{S}$ & $168^{\circ} 21.67^{\prime} \mathrm{E}$ \\
\hline & СР69 & 3 Sep. 1985 & $1220-1225$ & $23^{\circ} 51.38^{\prime} \mathrm{S}$ & $167^{\circ} 58.68^{\prime} \mathrm{E}$ \\
\hline & DW46 & 30 Aug. 1985 & $570-610$ & $22^{\circ} 53.05^{\prime} \mathrm{S}$ & $167^{\circ} 17.08^{\prime} \mathrm{E}$ \\
\hline \multirow[t]{3}{*}{ MUSORSTOM 4} & CC174 & 17 Sep. 1985 & 385 & $19^{\circ} 00.30^{\prime} \mathrm{S}$ & $163^{\circ} 18.50^{\prime} \mathrm{E}$ \\
\hline & DW205 & 27 Sep. 1985 & 160 & $22^{\circ} 38.50^{\prime} \mathrm{S}$ & $167^{\circ} 06.80^{\prime} \mathrm{E}$ \\
\hline & DW221 & 29 Sep. 1985 & $535-560$ & $22^{\circ} 58.60^{\prime} \mathrm{S}$ & $167^{\circ} 36.80^{\prime} \mathrm{E}$ \\
\hline MUSORSTOM 6 & DW423 & 16 Feb. 1989 & 280 & $20^{\circ} 25.85^{\prime} \mathrm{S}$ & $166^{\circ} 40.50^{\prime} \mathrm{E}$ \\
\hline \multirow{4}{*}{ SMIB 4} & DW40 & 7 Mar. 1989 & 260 & $24^{\circ} 46.20^{\prime} \mathrm{S}$ & $168^{\circ} 08.70^{\prime} \mathrm{E}$ \\
\hline & DW48 & 8 Mar. 1989 & 245 & $24^{\circ} 46.20^{\prime} \mathrm{S}$ & $168^{\circ} 08.70^{\prime} \mathrm{E}$ \\
\hline & DW55 & 9 Mar. 1989 & 260 & $23^{\circ} 21.40^{\prime} \mathrm{S}$ & $168^{\circ} 04.50^{\prime} \mathrm{E}$ \\
\hline & DW57 & 9 Mar. 1989 & 210 & $23^{\circ} 21.00^{\prime} \mathrm{S}$ & $168^{\circ} 21.00^{\prime} \mathrm{S}$ \\
\hline VOLSMAR & DW39 & 8 Jun. 1989 & 305 & $22^{\circ} 20.50^{\prime} \mathrm{S}$ & $168^{\circ} 43.50^{\prime} \mathrm{E}$ \\
\hline SMIB 6 & DW127 & 4 Mar. 1990 & $205-215$ & $19^{\circ} 06^{\prime} \mathrm{S}$ & $163^{\circ} 22^{\prime} \mathrm{E}$ \\
\hline \multirow{2}{*}{ BATHUS 2} & DW716 & 10 May 1993 & 290-308 & $22^{\circ} 40^{\prime} \mathrm{S}$ & $167^{\circ} 12^{\prime} \mathrm{E}$ \\
\hline & CP737 & 13 May 1993 & $357-400$ & $23^{\circ} 03.42^{\prime} \mathrm{S}$ & $166^{\circ} 59.97^{\prime} \mathrm{E}$ \\
\hline \multirow[t]{10}{*}{ BATHUS 3} & СР804 & 27 Nov. 1993 & $244-278$ & $23^{\circ} 41.40^{\prime} \mathrm{S}$ & $168^{\circ} 00.42^{\prime} \mathrm{E}$ \\
\hline & СР806 & 27 Nov. 1993 & $308-312$ & $23^{\circ} 42.31^{\prime} \mathrm{S}$ & $168^{\circ} 00.52^{\prime} \mathrm{E}$ \\
\hline & DW809 & 27 Nov. 1993 & $650-730$ & $23^{\circ} 39.39^{\prime} \mathrm{S}$ & $167^{\circ} 58.94^{\prime} \mathrm{E}$ \\
\hline & DW810 & 27 Nov. 1993 & $850-900$ & $23^{\circ} 40.45^{\prime} \mathrm{S}$ & $167^{\circ} 58.83^{\prime} \mathrm{E}$ \\
\hline & CP813 & 28 Nov. 1993 & $410-415$ & $23^{\circ} 45.23^{\prime} \mathrm{S}$ & $168^{\circ} 16.57^{\prime} \mathrm{E}$ \\
\hline & СР814 & 28 Nov. 1993 & $444-530$ & $23^{\circ} 47.60^{\prime} \mathrm{S}$ & $168^{\circ} 17.10^{\prime} \mathrm{E}$ \\
\hline & CP821 & 29 Nov. 1993 & $864-880$ & $23^{\circ} 19.16^{\prime} \mathrm{S}$ & $167^{\circ} 58.63^{\prime} \mathrm{E}$ \\
\hline & CP823 & 29 Nov. 1993 & $980-1000$ & $23^{\circ} 22.76^{\prime} \mathrm{S}$ & $167^{\circ} 51.60^{\prime} \mathrm{E}$ \\
\hline & DW829 & 29 Nov. 1993 & $386-390$ & $23^{\circ} 21.37^{\prime} \mathrm{S}$ & $168^{\circ} 01.84^{\prime} \mathrm{E}$ \\
\hline & DW830 & 29 Nov. 1993 & $361-365$ & $23^{\circ} 19.75^{\prime} \mathrm{S}$ & $168^{\circ} 01.45^{\prime} \mathrm{E}$ \\
\hline \multirow[t]{4}{*}{ BATHUS 4} & DW902 & 4 Aug. 1994 & $341-351$ & $19^{\circ} 00.84^{\prime} \mathrm{S}$ & $163^{\circ} 14.83^{\prime} \mathrm{E}$ \\
\hline & CP906 & 4 Aug. 1994 & $339-350$ & $19^{\circ} 01.07^{\prime} \mathrm{S}$ & $163^{\circ} 14.51^{\prime} \mathrm{E}$ \\
\hline & DW914 & 5 Aug. 1994 & $600-616$ & $18^{\circ} 48.79^{\prime} \mathrm{S}$ & $163^{\circ} 15.23^{\prime} \mathrm{E}$ \\
\hline & DW923 & 6 Aug. 1994 & $502-470$ & $18^{\circ} 51.51^{\prime} \mathrm{S}$ & $163^{\circ} 24.17^{\prime} \mathrm{E}$ \\
\hline \multirow[t]{7}{*}{ MUSORSTOM 8} & CP1001 & 25 Sep. 1994 & $150-250$ & $18^{\circ} 48.97^{\prime} \mathrm{S}$ & $168^{\circ} 59.83^{\prime} \mathrm{E}$ \\
\hline & DW1019 & 28 Sep. 1994 & $397-430$ & $17^{\circ} 38.25^{\prime} \mathrm{S}$ & $168^{\circ} 33.91^{\prime} \mathrm{E}$ \\
\hline & DW1021 & 28 Sep. 1994 & $124-130$ & $17^{\circ} 42.75^{\prime} \mathrm{S}$ & $168^{\circ} 37.00^{\prime} \mathrm{E}$ \\
\hline & CP1083 & 5 Oct. 1994 & $397-439$ & $15^{\circ} 51.91^{\prime} \mathrm{S}$ & $167^{\circ} 19.82^{\prime} \mathrm{E}$ \\
\hline & CP1084 & 5 Oct. 1994 & $207-280$ & $15^{\circ} 50.29^{\prime} \mathrm{S}$ & $167^{\circ} 17.88^{\prime} \mathrm{E}$ \\
\hline & CP1104 & 7 Oct. 1994 & $125-129$ & $15^{\circ} 03.83^{\prime} \mathrm{S}$ & $167^{\circ} 06.96^{\prime} \mathrm{E}$ \\
\hline & CP1131 & 11 Oct. 1994 & $140-175$ & $15^{\circ} 38.41^{\prime} \mathrm{S}$ & $167^{\circ} 03.52^{\prime} \mathrm{E}$ \\
\hline \multirow[t]{2}{*}{ MUSORSTOM 9} & DW1204 & 28 Aug. 1997 & $60-62$ & $9^{\circ} 52.6^{\prime} \mathrm{S}$ & $139^{\circ} 03.2^{\prime} \mathrm{W}$ \\
\hline & CP1265 & 3 Sep. 1997 & $90-92$ & $9^{\circ} 20.4^{\prime} \mathrm{S}$ & $140^{\circ} 07.3^{\prime} \mathrm{W}$ \\
\hline \multirow[t]{2}{*}{ BORDAU 1} & CP1447 & 4 Mar. 1999 & $420-513$ & $16^{\circ} 45.23^{\prime} \mathrm{S}$ & $179^{\circ} 59.13^{\prime} \mathrm{E}$ \\
\hline & CP1448 & 4 Mar. 1999 & $410-500$ & $16^{\circ} 45.04^{\prime} \mathrm{S}$ & $179^{\circ} 58.97^{\prime} \mathrm{E}$ \\
\hline LITHIST & DW13 & 12 Aug. 1999 & 400 & $23^{\circ} 45^{\prime} \mathrm{S}$ & $168^{\circ} 17^{\prime} \mathrm{E}$ \\
\hline \multirow{3}{*}{ BORDAU 2} & DW1513 & 1 Jun. 2000 & $190-221$ & $21^{\circ} 19^{\prime} \mathrm{S}$ & $175^{\circ} 01^{\prime} \mathrm{W}$ \\
\hline & CP1582 & 13 Jun. 2000 & $79-82$ & $18^{\circ} 41^{\prime} \mathrm{S}$ & $174^{\circ} 03^{\prime} \mathrm{W}$ \\
\hline & DW1595 & 16 Jun. 2000 & $523-806$ & $19^{\circ} 03^{\prime} \mathrm{S}$ & $174^{\circ} 19^{\prime} \mathrm{W}$ \\
\hline TAIWAN 1 & DW1 & 27 Jul. 2000 & 98 & $23^{\circ} 38.1^{\prime} \mathrm{N}$ & $119^{\circ} 50.9^{\prime} \mathrm{E}$ \\
\hline \multirow[t]{8}{*}{ NORFOLK 1} & DW1659 & 20 Jun. 2001 & $467-449$ & $23^{\circ} 38^{\prime} \mathrm{S}$ & $167^{\circ} 42^{\prime} \mathrm{E}$ \\
\hline & DW1666 & 20 Jun. 2001 & $469-860$ & $23^{\circ} 42^{\prime} \mathrm{S}$ & $167^{\circ} 43^{\prime} \mathrm{E}$ \\
\hline & DW1667 & 21 Jun. 2001 & $237-250$ & $23^{\circ} 41^{\prime} \mathrm{S}$ & $168^{\circ} 01^{\prime} \mathrm{E}$ \\
\hline & DW1699 & 24 Jun. 2001 & $581-600$ & $24^{\circ} 40^{\prime} \mathrm{S}$ & $168^{\circ} 39^{\prime} \mathrm{E}$ \\
\hline & DW1704 & 25 Jun. 2001 & $420-400$ & $23^{\circ} 47^{\prime} \mathrm{S}$ & $168^{\circ} 17^{\prime} \mathrm{E}$ \\
\hline & DW1712 & 26 Jun. 2001 & $180-250$ & $23^{\circ} 22^{\prime} \mathrm{S}$ & $168^{\circ} 03^{\prime} \mathrm{E}$ \\
\hline & CP1719 & 26 Jun. 2001 & $391-407$ & $23^{\circ} 21^{\prime} \mathrm{S}$ & $168^{\circ} 02^{\prime} \mathrm{E}$ \\
\hline & DW 1722 & 26 Jun. 2011 & 540 & $23^{\circ} 16^{\prime} \mathrm{S}$ & $168^{\circ} 01^{\prime} \mathrm{E}$ \\
\hline & DW118 & 31 Jul. 2001 & $128-136$ & $24^{\circ} 56.3^{\prime} \mathrm{N}$ & $122^{\circ} 01.5^{\prime} \mathrm{E}$ \\
\hline \multirow[t]{4}{*}{ SALOMON 1} & DW1741 & 23 Sep. 2001 & $557-655$ & $11^{\circ} 29^{\prime} \mathrm{S}$ & $159^{\circ} 57^{\prime} \mathrm{E}$ \\
\hline & DW1756 & 26 Sep. 2001 & $497-511$ & $08^{\circ} 52^{\prime} \mathrm{S}$ & $159^{\circ} 50^{\prime} \mathrm{E}$ \\
\hline & DW1767 & 28 Sep. 2001 & $98-200$ & $08^{\circ} 19^{\prime} \mathrm{S}$ & $160^{\circ} 40^{\prime} \mathrm{E}$ \\
\hline & DW1854 & 7 Oct. 2001 & $229-260$ & $09^{\circ} 46^{\prime} \mathrm{S}$ & $160^{\circ} 53^{\prime} \mathrm{E}$ \\
\hline
\end{tabular}




\section{Geographical distribution}

The known area of distribution ranges from Indonesia and Tuvalu in the south, through Japan in the north, and encompasses the Philippines and the South China Sea (Schuchert 2015).

Genus Diphasia L. Agassiz, 1862

Diphasia cristata Billard, 1920

Fig. 1C-J

Diphasia cristata Billard, 1920: 147, fig. 1f.

Diphasia cristata - Billard 1925b: 218, fig. 57, pl. 3 fig. 32. - Hirohito 1983: 38, fig. 15; 1995: 161, fig. 51a-c.

\section{Material examined}

SMIB 4: Stn. DW57, several sterile stems and fragments, up to $2.5 \mathrm{~cm}$ high (MNHN-IK-2012-16509).

SMIB 6: Stn. DW127, a female colony composed of several stems up to $4 \mathrm{~cm}$ high, epizoic on Gonaxia sp. (MNHN-IK-2012-16510).

MUSORSTOM 8: Stn. DW1021, small female colony composed of a few stems, up to $2 \mathrm{~cm}$ high, epizoic on Caminothujana molukkana (MNHN-IK-2012-16511).

BORDAU 1: Stn. CP1447, small female colony composed of several stems up to $2.4 \mathrm{~cm}$ high (MNHNIK-2012-16512); Stn. CP1448, dense, fertile colony (or colonies?), up to $4 \mathrm{~cm}$ high, on dead antipatharian (MNHN-IK-2012-16513).

BORDAU 2: Stn. DW1513, male and female colonies with stems up to $1.5 \mathrm{~cm}$ high, on antipatharian and aglaopheniid hydroid (MNHN-IK-2012-16514).

\section{Remarks}

This species is immediately recognizable through the presence of five prominent, longitudinal, perisarcal crests running over the whole body of hydrothecae, as well as of an additional one found on the dorsal side of the internodes. For the most recent description, see Hirohito (1995). It should be noted that the oblique node demarcating the junction between the basal, ahydrothecate part and the main, distal, hydrothecate part of the stems and side branches is not always present in the material examined here.

The gonothecae of this species, hitherto unknown, are described from the present material. Male and female gonothecae present, each sex borne on different stems, but, due to their high density and the numerous branches and anastomoses of the stolon, it is impossible to determine if it is a single colony or whether several colonies are represented. The male gonothecae (Fig. 1I-J) are 1505-1580 $\mu \mathrm{m}$ long, ovoid (480-530 $\mu \mathrm{m}$ wide in middle), and provided with numerous upturned spines (width including the spines $1000-1170 \mu \mathrm{m}$ ). The aperture occurs on the apex of a short neck region and is surrounded by a few, short spines. The female gonothecae (Fig. 1F-H) are comparatively larger (2985-3160 $\mu \mathrm{m}$ long), have a rhomboidal cross-section (940-1010 $\mu \mathrm{m}$ wide), forming four crests at each angle; each one is provided with a succession of moderately long, upturned spines (width of gonotheca including the spines ca $1300 \mu \mathrm{m}$ ). A central, piriform chamber is attached to the walls of the gonotheca through four perisarcal connections, whose position alternates with that of the crests. The aperture is situated apically, and is small and quadrangular. 
GALEA H.R., Sertulariid hydroids from the tropical western Pacific

\section{Geographical distribution}

Previously known from the Philippines (Billard 1920, 1925b) and Japan (Hirohito 1983, 1995). The present material originates from New Caledonia, Vanuatu, Fiji, and Tonga.

Diphasia orientalis Billard, 1920

Fig. 1K

Diphasia orientalis Billard, 1920: 146, fig. 1d.

Diphasia orientalis - Billard 1925b: 212, figs 52-53. — Gibbons \& Ryland 1989: 407, fig. 26.

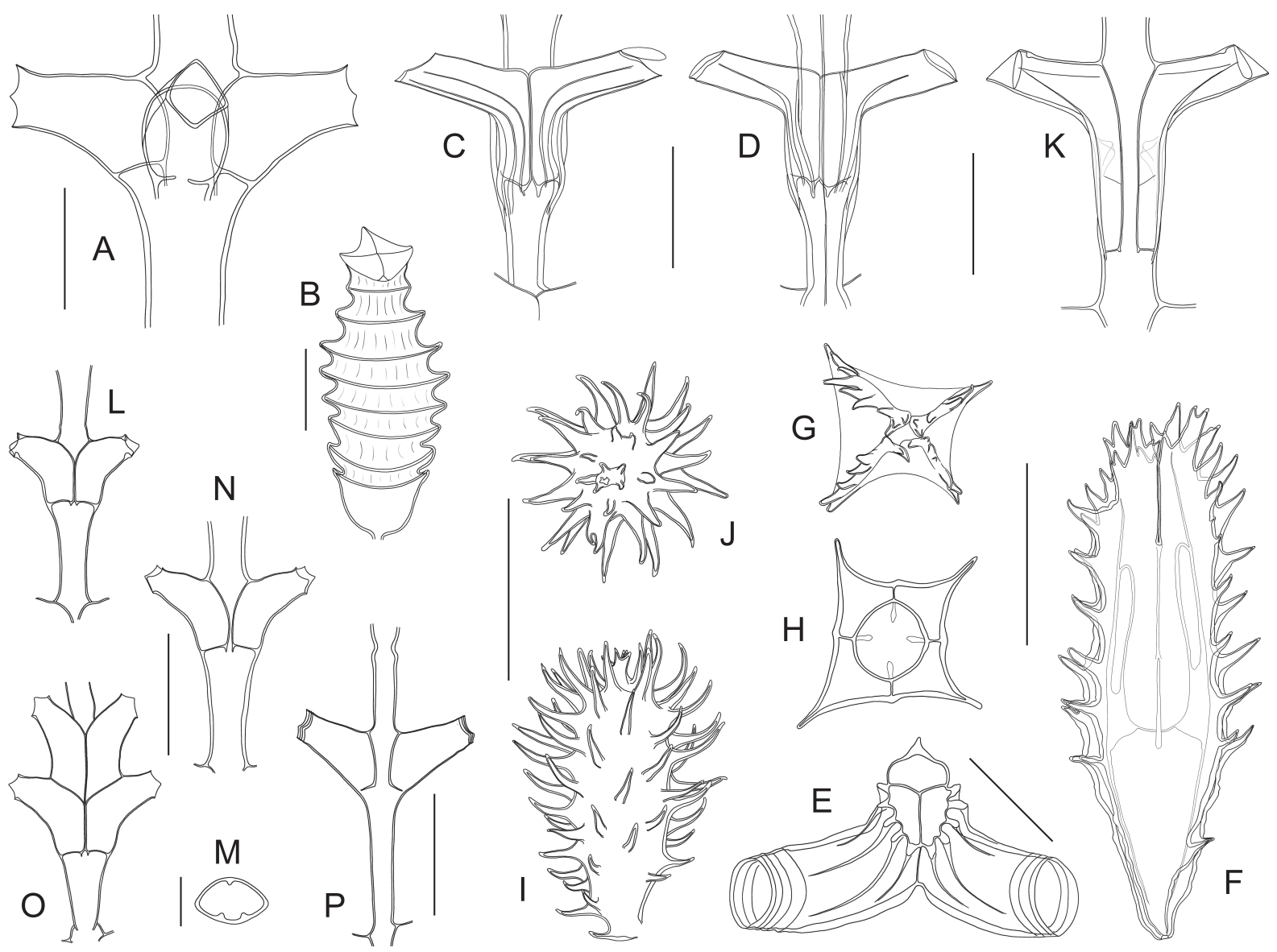

Fig. 1. - A-B. Caminothujaria molukkana von Campenhausen, 1896 (BORDAU 2, Stn. CP1582). A. Fragment of internode with verticil of hydrothecae. B. Gonotheca. - C-J. Diphasia cristata Billard, 1920 (BORDAU 1, Stn. CP1448). C. Pair of hydrothecae, frontal view. D. Same, dorsal view. E. Cross section through basal part of hydrothecal pair, showing perisarcal crests. F. Female gonotheca. G. Same, apical view. H. Same, cross section. I. Male gonotheca. J. Same, apical view. - K. Diphasia orientalis Billard, 1920 (MUSORSTOM 3, Stn. DR117), internode with pair of hydrothecae. - L-O. Dynamena heterodonta (Jarvis, 1922) (MUSORSTOM 9). L. Pair of hydrothecae in material from Stn. DW1204. M. Same sample, hydrothecal aperture, showing internal, submarginal cusps. N-O. Isolated (N) or stacked (O) pairs of hydrothecae in material from Stn. CP1265. - P. Geminella ceramensis Billard, 1925a (MUSORSTOM 8, Stn. CP1084), internode with pair of hydrothecae. Scale bars: A-D, K-L, $\mathrm{N}-\mathrm{P}=500 \mu \mathrm{m} ; \mathrm{E}=400 \mu \mathrm{m} ; \mathrm{F}-\mathrm{J}=1 \mathrm{~mm} ; \mathrm{M}=100 \mu \mathrm{m}$. 


\section{Material examined}

MUSORSTOM 3: Stn. DR117, two infertile, unbranched stems, 9 and $12 \mathrm{~mm}$ high, detached from substrate (MNHN-IK-2012-16515); Stn. CP121, two infertile, unbranched stems, 13 and $22 \mathrm{~mm}$ high, detached from substrate (MNHN-IK-2012-16516).

\section{Remarks}

For a thorough description of this species, see Billard (1925b).

\section{Geographical distribution}

Indonesia (Billard 1925b), Fiji (Gibbons \& Ryland 1989), Philippines (present report).

Genus Dynamena Lamouroux, 1812

Dynamena heterodonta (Jarvis, 1922)

Fig. 1L-O

Pasythea heterodonta Jarvis, 1922: 344, pl. 24, figs 11-12.

Dynamena heterodonta - Billard 1925b: 198, fig. 44. — Redier 1966: 86. - Vervoort \& Vasseur 1977: 36, figs 16-17.

Sertularia gracilis - Billard 1905: 334 (not Sertularia gracilis Hassall, 1848: 2223).

non Dynamena quadridentata f. heterodonta - Vannucci 1951a: 83; 1951b: 108, 112, 114 [= D. quadridentata (Ellis \& Solander, 1786)].

\section{Material examined}

MUSORSTOM 9: Stn. DW1204, small colony composed of four infertile stems, 6-12 cm high, detached from substrate (MNHN-IK-2012-16517); Stn. DW1265, sterile colony with stems up to $2.6 \mathrm{~cm}$ high, epizoic on Synthecium sp. (MNHN-IK-2012-16518).

\section{Remarks}

The sterile, unbranched stems, divided here and there by oblique nodes, each of which comprises a varied number of isolated hydrothecal pairs, occasionally forming apically stacked groups of two, the lack of evidence of an abcauline caecum in retracted hydranths, the two-cusped hydrothecae with a pleated adcauline flap and a semicircular abcauline flap, and the inconstant presence of internal, submarginal cusps in the hydrothecae suggest that they belong, with little doubt, to Jarvis' (1922) species.

Vervoort \& Vasseur (1977) provided a reexamination of the type material, as well as a discussion regarding its differences with $D$. quadridentata (Ellis \& Solander, 1786).

\section{Geographical distribution}

St. Brandon (Cargados Carajos) (Jarvis 1922), Indonesia (Billard 1925b), New Caledonia (Redier 1966), French Polynesia [Billard (1905), as Sertularia gracilis Hassall, 1848; Vervoort \& Vasseur (1977); present study]. 
GALEA H.R., Sertulariid hydroids from the tropical western Pacific

Genus Geminella Billard, 1925b

Geminella ceramensis (Billard, 1925a)

Fig. 1P

Sertularella ceramensis Billard, 1925a: 649.

Geminella ceramensis - Schuchert 2003: 174, fig. 31.

\section{Material examined}

MUSORSTOM 8: Stn. CP1084, small, sterile colony, less than $1 \mathrm{~cm}$ high, with tangled stems fixed on calcareous substrate (MNHN-IK-2012-16519); Stn. CP1131, two sterile stems $0.5 \mathrm{~cm}$ high, detached from substrate (MNHN-IK-2012-16520).

\section{Remarks}

For a redescription of this distinctive species, see Schuchert (2003), who also provided a synonymy.

\section{Geographical distribution}

Indonesia, Philippines, New Caledonia (Schuchert 2003), and Vanuatu (present study).

Genus Gonaxia Vervoort, 1993

Gonaxia amphorifera Vervoort, 1993

Figs $2 \mathrm{~A}, 3 \mathrm{~A}-\mathrm{B}$

Gonaxia amphorifera Vervoort, 1993: 117, figs 3f, 4, 5, 6a-b, 8a.

\section{Material examined}

SMIB 6: Stn. DW127, two colonies, one unbranched and $4.5 \mathrm{~cm}$ high, the other forked twice and $9 \mathrm{~cm}$ high, both bear male gonothecae (MNHN-IK-2012-16521).

\section{Remarks}

The difficulty of distinguishing G. amphorifera from G. ampullacea Vervoort, 1993 without their female gonothecae is notorious. Since the present material bears only male gonothecae, attention was focused on the hydrothecal features, in an attempt to separate them specifically. Although Vervoort (1993) emphasized several distinguishing characters, the distinction was still laborious and, eventually, two features proved useful. It was found that in the present species the free, distal part of the hydrocladial hydrothecae was constantly set at about $90^{\circ}$ with the axis of the cladia, regardless the position of the thecae (Fig. 2A) while, in the following species, that angle varied considerably (Fig. 2B) between the proximal hydrothecae (where it was of $80-90^{\circ}$ ) and the distalmost ones (usually reaching $45^{\circ}$ ). The size of the hydrothecae was comparatively smaller in the present material (Fig. 3A) than in that assigned to G. ampullacea Vervoort, 1993 (Fig. 3C). I believe that the lack of a distinct inflation of the hydrothecae invoked by Vervoort is misleading.

Some hydrothecae exhibit incipient lateral diverticuli (Fig. 3A). Their structure is discussed under G. aff. similis Vervoort, 1993.

\section{Geographical distribution}

New Caledonia (Vervoort 1993; present study). 
Gonaxia ampullacea Vervoort, 1993

Figs 2B, 3C-D

Gonaxia ampullacea Vervoort, 1993: 121, figs 6c, 7a-c, 9.

\section{Material examined}

BATHUS 4: DW914, a $3.5 \mathrm{~cm}$ high colony with unbranched stem, bearing male gonothecae (MNHNIK-2012-16522).

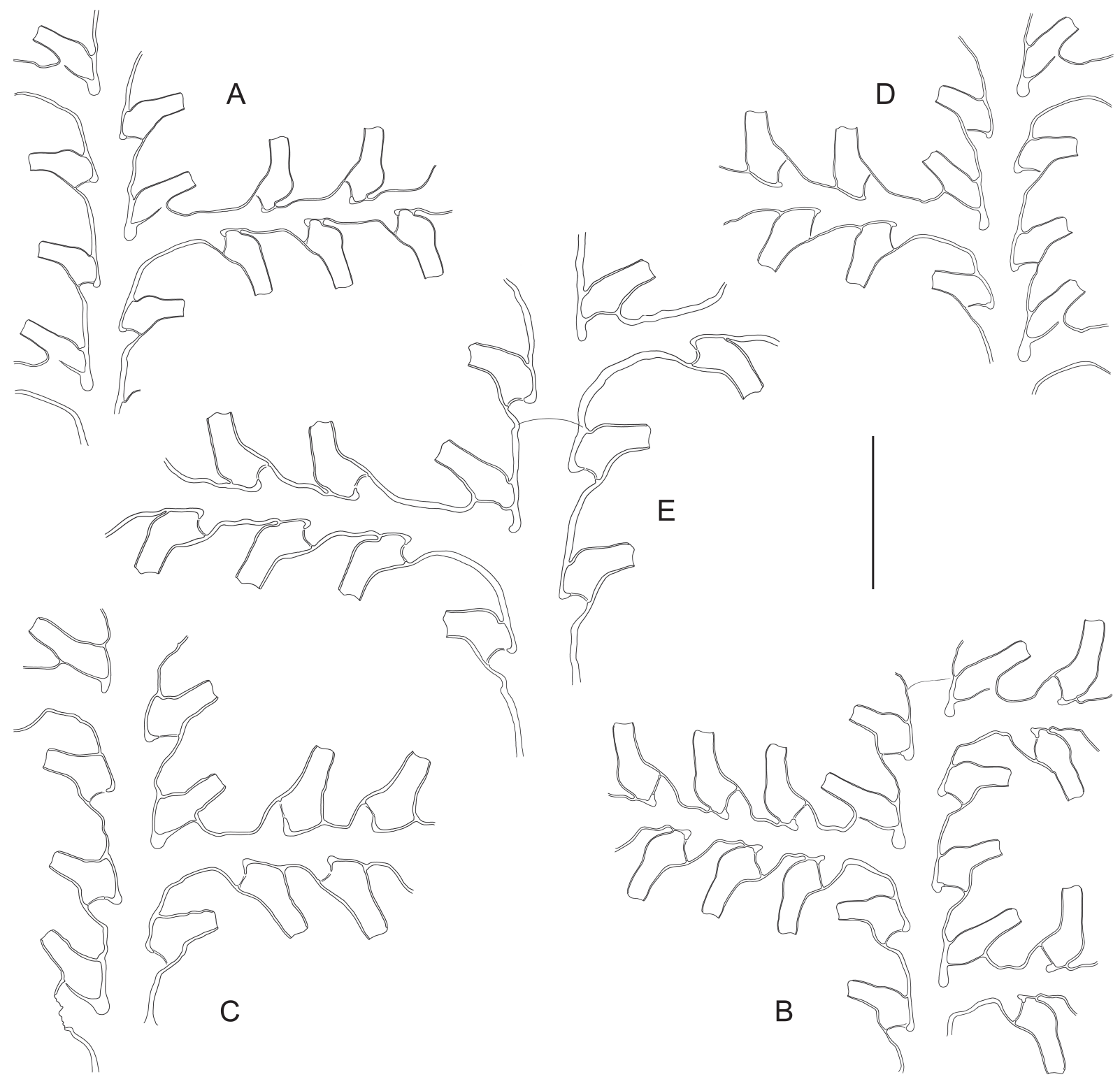

Fig. 2. - A. Gonaxia amphorifera Vervoort, 1993 (SMIB 6, Stn. DW127), portion of stem with cladium. - B. Gonaxia ampullacea Vervoort, 1993 (BATHUS 4, Stn. DW914), portion of stem with cladia. - C. Gonaxia compacta Vervoort, 1993 (BATHUS 4, Stn. DW923), portion of stem with cladium. - D. Gonaxia intermedia Vervoort, 1993 (BATHUS 4, Stn. CP906), portion of stem with cladium. - E. Gonaxia sinuosa Vervoort, 1993 (SMIB 4, Stn. DW40), portion of stem with cladia. Scale bar: A-E $=1 \mathrm{~mm}$. 
GALEA H.R., Sertulariid hydroids from the tropical western Pacific

\section{Remarks}

As stated above, the larger size and the more acute angle formed by the free part of the hydrocladial hydrothecae with the axis of cladia were used to assign this material to G. ampullacea. As in G. amphorifera, some hydrothecae exhibit incipient lateral diverticuli (Fig. 3C).

\section{Geographical distribution}

New Caledonia (Vervoort 1993; present study).

Gonaxia compacta Vervoort, 1993

Figs $2 \mathrm{C}, 3 \mathrm{E}-\mathrm{F}$

Gonaxia compacta Vervoort, 1993: 135, figs 8c, 14a-b, 15a.

\section{Material examined}

BATHUS 4: Stn. DW923, a single, $6 \mathrm{~cm}$ high colony bearing an abortive gonotheca, as well as a row of incipient gonothecae, highly obscured by the accessory tubes of the stem (MNHN-IK-2012-16523).

\section{Remarks}

As already stated by Vervoort (1993), the hydrothecae of this species bear an obvious resemblance to those of G. amphorifera, G. ampullacea, and G. sinuosa, but it could be readily distinguished from them on the account of the absence of a pit formed by the free adaxial wall with the internode (Fig. 3E). Only an abortive gonotheca, arising from within the first hydrotheca of a cladium (Fig. 3F), was found. Several successive, elongate masses among the accessory tubes of the stem suggest the imminent formation of normal gonothecae.

\section{Geographical distribution}

New Caledonia (Vervoort 1993; present study).

Gonaxia intermedia Vervoort, 1993

Figs 2D, 3G-K

Gonaxia intermedia Vervoort, 1993: 157, figs 23e, 24d, 25a-c, $26 a$.

\section{Material examined}

BATHUS 4: Stn. DW902, several colonies and fragments, up to $9.5 \mathrm{~cm}$ high, mostly fertile, bearing male gonothecae (MNHN-IK-2012-16524); Stn. CP906, a total of twelve fertile colonies (10 male and 2 female), 4-6 cm high (MNHN-IK-2012-16525).

\section{Remarks}

In some colonies, the length of cladia reaches as much as $2.8 \mathrm{~cm}$, and each may bear up to 116 hydrothecae. Aberrant secondary cladia, as those occurring in specimens from Stn. DW902, are given off from either within some cladial hydrothecae (Fig. 3J), or from short, auxiliary cladial tubes running parallel to the proximal parts of the axes of cladia.

Both male and female colonies are present in the material in hand. As stated by Vervoort (1993), the gonothecae of this species resemble those of G. amphorifera and G. ampullacea through their general shape and nearly fully adnate condition. They seem to originate from below the axillar hydrothecae. The distal part of a gonotheca overlaps the proximal part of the following one, though their bodies never fuse with each other. Their apertures (50-65 $\mu \mathrm{m}$ wide in males, and 250-290 $\mu \mathrm{m}$ wide in females) 
are mounted on raised cones situated near the distal ends of their bodies. In the male colonies, the gonothecae are so obscured by the numerous auxiliary tubes running parallel to the stem, that only the tips of their neck regions protrude from the strongly fascicled mass which composes the stems. In one male specimen (from Stn. CP906) with otherwise normal gonothecae, an elongate, abortive gonotheca, with two distal apertures, is given off from the lumen of a cladial hydrotheca The occurrence of such

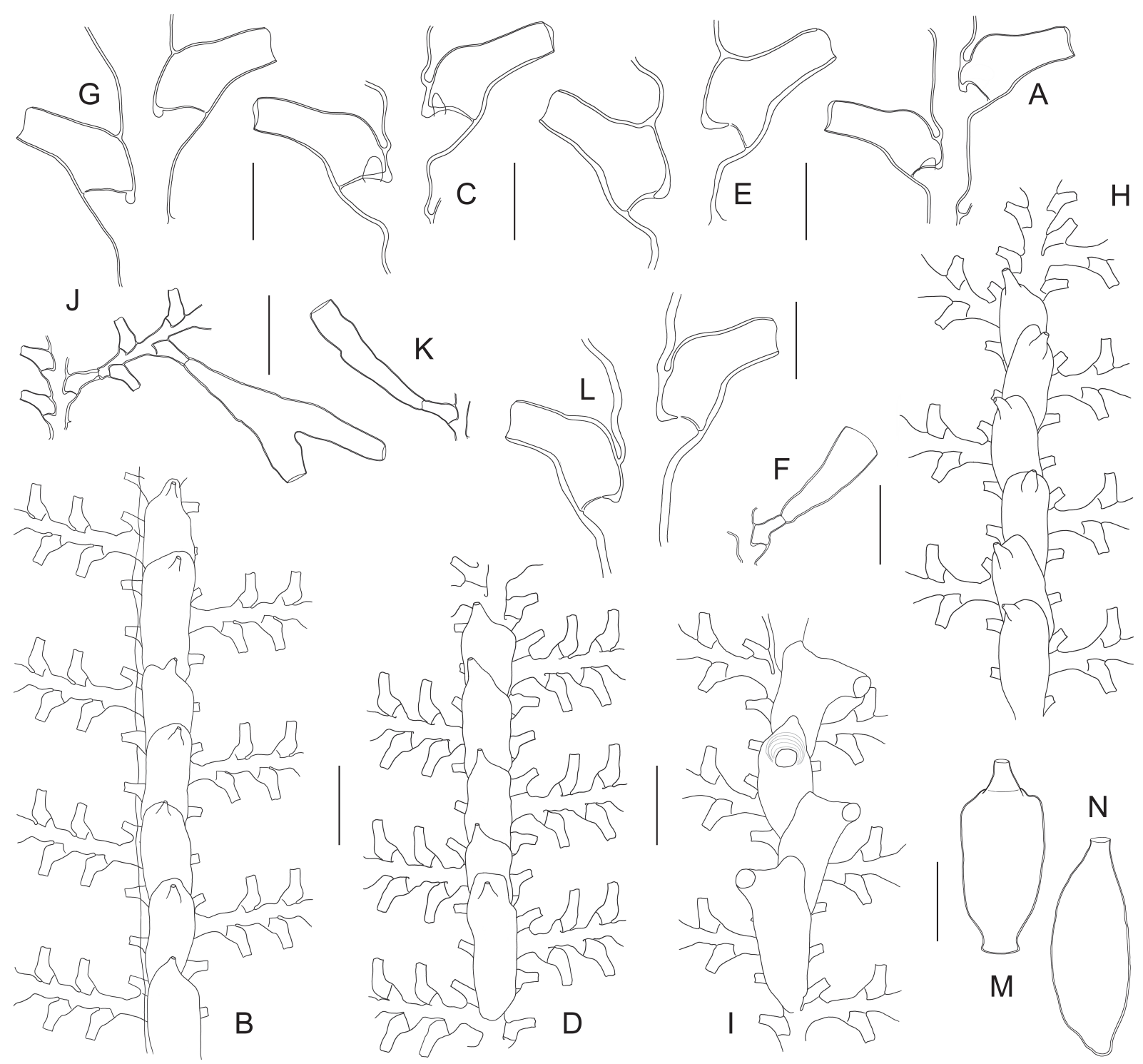

Fig. 3. - A-B. Gonaxia amphorifera Vervoort, 1993 (SMIB6, Stn. DW127). A. Two successive cladial internodes with their hydrothecae. B. Portion of stem with male gonothecae. - C-D. Gonaxia ampullacea Vervoort, 1993 (BATHUS 4, Stn. DW914). C. Two successive cladial internodes with their hydrothecae. D. Portion of stem with male gonothecae. - E-F. Gonaxia compacta Vervoort, 1993 (BATHUS 4, Stn. DW923). E. Two successive cladial internodes with their hydrothecae. F. Abortive gonotheca (of undetermined sex) originating from within a hydrotheca. - G-K. Gonaxia intermedia Vervoort, 1993 (BATHUS 4). G. Two successive cladial internodes with their hydrothecae (Stn. CP906). H. Portion of stem with male gonothecae (Stn. CP906). I. Portion of stem with female gonothecae (Stn. CP906). J-K. Abortive gonothecae arising from hydrothecal lumina (Stn. DW902). - L-N. Gonaxia sinuosa Vervoort, 1993 (SMIB 4, DW40). L. Two successive cladial internodes with their hydrothecae. M-N. Two female gonothecae. Scale bars: A, C, E, G, L = $300 \mu \mathrm{m}$; B, D, F, H-K, M-N = 1 mm. 
GALEA H.R., Sertulariid hydroids from the tropical western Pacific

gonothecae is considerable in the material from Stn. DW902, and specimens with one (Fig. 3K), two (Fig. 3J), or exceptionally three apertures could be seen. These so called abortive gonothecae may prove fully functional, as they are provided with apertures. However, their lumina are empty in the specimens in hand, and this assumption could not be checked at this stage.

\section{Geographical distribution}

New Caledonia (Vervoort 1993; present study).

Gonaxia sinuosa Vervoort, 1993

Figs 2E, 3L-N

Gonaxia sinuosa Vervoort, 1993: 179, figs 31c-e, 35b, 37a-b, 38a.

\section{Material examined}

SMIB 4: Stn. DW40, an originally $8 \mathrm{~cm}$ high colony with simple stem, now broken into two parts, bearing male gonothecae (MNHN-IK-2012-16526); Stn. DW48, an originally $5.5 \mathrm{~cm}$ high, sterile colony with simple stem, now broken into two unequal parts (MNHN-IK-2012-16527).

BATHUS 2: Stn. DW716, six colonies and fragments, 2.3-9.1 cm high, with simple or branched stems, two of which are sterile, two others bear male gonothecae, and the remaining two carry female gonothecae (MNHN-IK-2012-16528).

BATHUS 3: Stn. CP804, eleven colonies and fragments, 1.5-4.9 cm high, all with simple stems, of which four are sterile, three bear male gonothecae, and the remaining four bear female gonothecae (MNHN-IK-2012-16529); Stn. DW829, two colonies with simple stems, 3.8 and $2.4 \mathrm{~cm}$ high, the latter devoid of its basal part, and bearing three incipient gonothecae (MNHN-IK-2012-16530).

\section{Remarks}

The shape of the hydrothecae (Fig. 3L), as well as the condition and morphology of the gonothecae (Fig. 3M-N) are characteristic. One stem from BATHUS 2, Stn. DW716 is fully fertile (male) and bears its gonothecae in two parallel rows, each one originating from below the base of an axillar hydrotheca. The female stems examined here bear a lesser number of gonothecae.

\section{Geographical distribution}

New Caledonia (Vervoort 1993; present study), Norfolk Ridge (Vervoort 1993).

\section{Gonaxia crassicaulis Vervoort, 1993}

Fig. 4A

Gonaxia crassicaulis Vervoort, 1993: 145, figs 18c-d, 19a-b.

\section{Material examined}

MUSORSTOM 4: Stn. DW205, a cladium, 2.5 cm long (MNHN-IK-2012-16531).

NORFOLK 1: Stn. DW1712, an infertile colony, $3.8 \mathrm{~cm}$ high (MNHN-IK-2012-16532).

\section{Remarks}

According to Vervoort (1993), G. crassicaulis is easily recognizable through the characteristic development of the perisarc, forming thick, internal, longitudinal ridges, connecting the adnate adaxial walls of the hydrothecae in each row (Fig. 4A). 


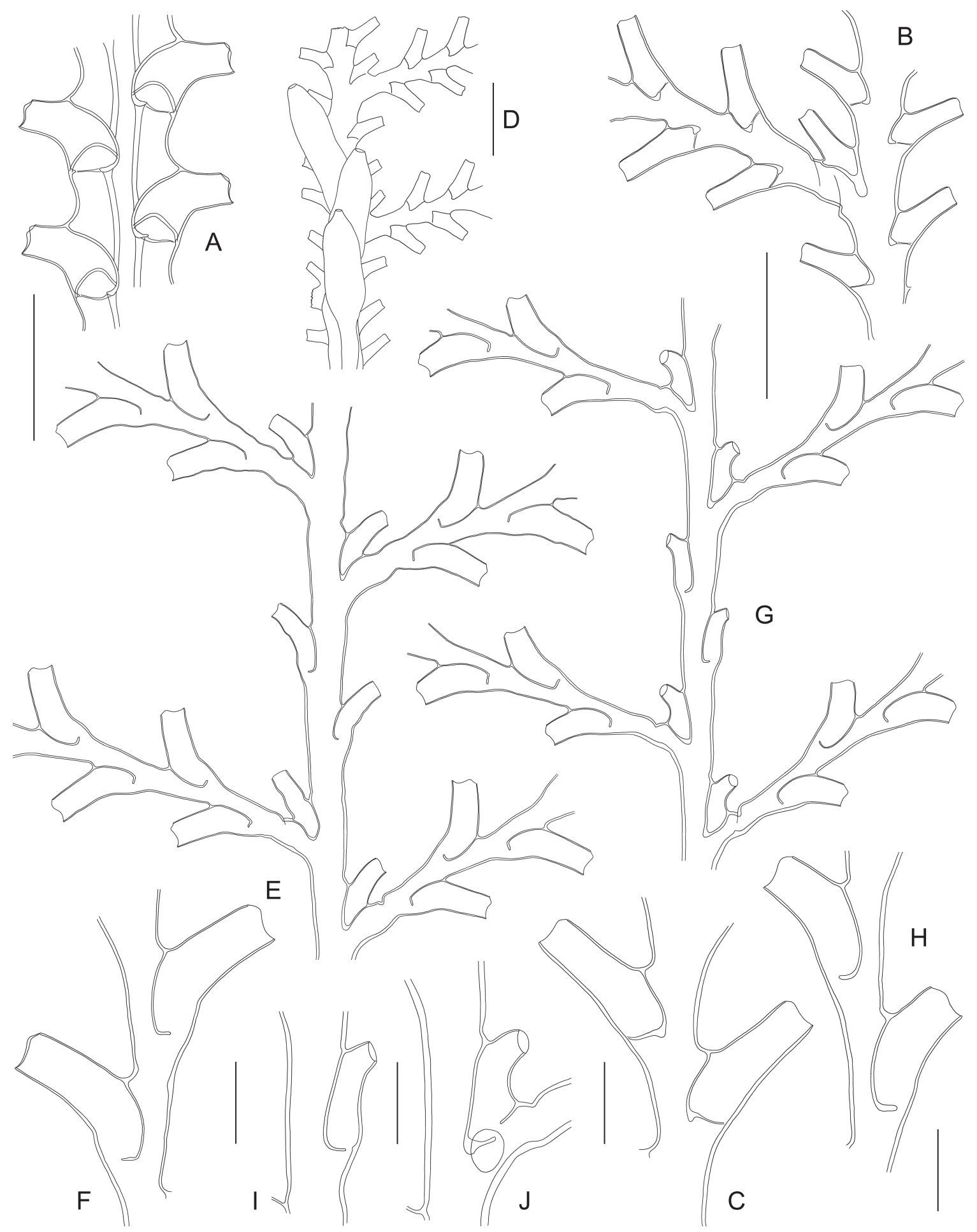

Fig. 4. - A. Gonaxia crassicaulis Vervoort, 1993 (MUSORSTOM 4, Stn. DW205), portion of cladium. - B-D. Gonaxia elegans Vervoort, 1993 (BATHUS 3, Stn. DW809). B. Portion of stem and basal part of a cladium. C. Two consecutive internodes with their hydrothecae. D. Portion of stem with male gonothecae. - E-F. Gonaxia cf. errans Vervoort, 1993 (BATHUS 2, Stn. CP737). E. Distalmost portion of stem with basal parts of four hydrocladia. F. Two consecutive cladial internodes with their hydrothecae. - G-J. Gonaxia plumularioides sp. nov. (BIOCAL, Stn. CP34). G. Distalmost part of a stem, showing the structure of internodes. H. Two consecutive cladial internodes with their hydrothecae. I. Stem hydrotheca. J. Axillar hydrotheca. Scale bars: A-B, D-E, G $=1 \mathrm{~mm}$; C, F, H-J = $300 \mu \mathrm{m}$. 
GALEA H.R., Sertulariid hydroids from the tropical western Pacific

Also characteristic is the presence of large, internal, semi-circular "thickenings" of the perisarc (Fig. 4A), arching over the basal foramina, when the hydrothecae are seen laterally. These structures, one situated in the "frontal" aspect of the hydrothecae, the other on their "dorsal" side, correspond in fact to the attachment points of the hydrothecal bases to the lateral walls of the thecae which, in this species, are raised above the level of the foramina. When the hydrothecae are seen facing their apertures, the hydrothecal bases appear U-shaped, the foramina being situated at the bottom of this concavity.

\section{Geographical distribution}

New Caledonia (present study), Norfolk Ridge (Vervoort 1993).

Gonaxia elegans Vervoort, 1993

Fig. 4B-D

Gonaxia elegans Vervoort, 1993: 153, figs 19c, 21b-c, 22.

\section{Material examined}

BATHUS 3: Stn. DW809, a $4.4 \mathrm{~cm}$ high colony devoid of hydrorhiza and bearing female gonothecae, as well as an originally $5.4 \mathrm{~cm}$ high colony (now broken into two parts) bearing male gonothecae and several broken cladia originating from both colonies (MNHN-IK-2012-16533).

\section{Remarks}

This species is immediately recognizable through the characteristic position and shape of its hydrothecae. The $5.4 \mathrm{~cm}$ high colony is evidently male when compared to the smaller one, which bears gonothecae possessing much wider apertures. Only the female gonothecae were described by Vervoort (1993) but, upon a careful inspection of the present material, it should be stated that they do not arise from the accessory tubes on the hydrocaulus, but from the main tube itself, as this is indisputably seen in the monosiphonic part of the stem. In addition, in this colony at least, nearly all accessory tubes are found on the "dorsal" aspect of the stem, while the row of gonothecae is situated on its "front".

The male gonothecae, observed here for the first time, are similar in shape to the female ones, and also arise from the main tube of the stem, but in both the frontal and dorsal aspects of the colony. They are given off closely and in a single row (Fig. 4D), are about half adnate, and their free parts are shifted alternately left and right; their bases are obscured by the numerous accessory tubes running up the stem. They are long $(1.5-2 \mathrm{~mm})$, tubular (480-520 $\mu \mathrm{m}$ wide), with small, circular apertures $(100-120 \mu \mathrm{m}$ wide) mounted on the summit of a conical, distal neck region.

\section{Geographical distribution}

New Caledonia (Vervoort 1993; present study), Norfolk Ridge (Vervoort 1993).

\section{Gonaxia cf. errans Vervoort, 1993}

Fig. 4E-F

Gonaxia errans Vervoort, 1993: 154, figs 23a-d, 24a-c.

\section{Material examined}

BATHUS 2: Stn. CP737, two stem fragments, 13 and $9 \mathrm{~mm}$ high, the former corresponding to the middle part of a colony, while the latter is likely the distalmost end of (another?) colony; both are sterile; several broken cladia are also present (MNHN-IK-2012-16534). 


\section{Remarks}

The pattern of cladial arrangement on the stem in this scarce material seems to follow a rather peculiar sequence: each equivalent of internode (the nodes are inconspicuous) has a proximal apophysis with its associated axillar hydrotheca, two alternate hydrothecae above, as well as a second, distal apophysis (on the side opposite to the former) with its associated axillar hydrotheca; the same sequence is repeated on the following "internode" but, there, it is the opposite image of the preceding one. In the distalmost part of one of the available colony fragments, two successive cladia occur on the same side, and are separated on the opposite side by a single stem hydrotheca. According to Vervoort (1993), the cladial arrangement is varied, with "zero to three hydrothecae between two successive apophyses", which is apparently the case in the present material.

The shape of the hydrothecae also fits the original description of G. errans, though they are comparatively shorter in the material in hand (free adaxial side 335-365 $\mu \mathrm{m}$, adnate adaxial side 280-300 $\mu \mathrm{m}$, abaxial side $490-510 \mu \mathrm{m}$ ), but seem to have almost the same width (maximum width 205-220 $\mu \mathrm{m}$, diameter at aperture $165-175 \mu \mathrm{m}$ ) as in Vervoort's samples. Consequently, the present material is provisionally assigned to G. errans.

\section{Geographical distribution}

New Caledonia (present study), Norfolk Ridge (Vervoort 1993).

Gonaxia plumularioides sp. nov. urn:1sid:zoobank.org:act:6A07FF84-EAA6-4AE6-8755-B450B17A28EB

Fig. 4G-J; Table 2

\section{Diagnosis}

Gonaxia with slender, fascicled, branched or unbranched stems; cladia monosiphonic. Equivalents of internodes composed of a proximal hydrocladial apophysis and its associated axillary hydrotheca, two alternate hydrothecae above, and a second, distal hydrocladial apophysis and its associated hydrotheca. Hydrothecae tubular, slightly curved up- and outwards, comparatively slender and more immersed on stem than on cladia. Gonothecae unknown.

\section{Etymology}

From the Latin plüma, meaning feather, and the Greek $\varepsilon \tilde{i} \delta o \varsigma$, meaning likeness, with reference to their plumose appearance, recalling the branching pattern displayed by some hydroids belonging to the superfamily Plumularioidea.

\section{Material examined}

Holotype

BIOCAL: Stn. CP34, a $2.8 \mathrm{~cm}$ high, distal fragment of a branch or a stem, itself branched twice, sterile (MNHN-IK-2012-16535).

\section{Paratype}

BIOCAL: Stn. CP34, a $7.7 \mathrm{~cm}$ high, unbranched colony devoid of its hydrorhiza, as well as a $1 \mathrm{~cm}$ high fragment corresponding to the distalmost part of a colony; both are sterile (MNHN-IK-2012-16536).

\section{Description}

Colonies attaining at least $8 \mathrm{~cm}$ high, composed of either simple or ramified stems of slender appearance, despite being fascicled; accessory tubes on both "frontal" and "dorsal" sides of stems; the latter uniformly grading to monosiphonic distally. Side branches, when present, arising only in 
GALEA H.R., Sertulariid hydroids from the tropical western Pacific

Table 2. Measurements (in $\mu \mathrm{m}$ ) of hydrothecae of Gonaxia plumularioides sp. nov. and G. nova sp. nov.

\begin{tabular}{lcccccc}
\hline & \multicolumn{3}{c}{ G. plumularioides sp. nov. } & & G. nova sp. nov. \\
\cline { 2 - 7 } & $\begin{array}{c}\text { Caulinar } \\
\text { hydrotheca }\end{array}$ & $\begin{array}{c}\text { Axillar } \\
\text { hydrotheca }\end{array}$ & $\begin{array}{c}\text { Cladial } \\
\text { hydrotheca }\end{array}$ & $\begin{array}{c}\text { Caulinar } \\
\text { hydrotheca }\end{array}$ & $\begin{array}{c}\text { Axillar } \\
\text { hydrotheca }\end{array}$ & $\begin{array}{c}\text { Cladial } \\
\text { hydrotheca }\end{array}$ \\
\hline Free adaxial side & $85-125$ & $75-140$ & $180-210$ & $555-575$ & $565-630$ & $580-615$ \\
Adnate adaxial side & $355-380$ & $360-440$ & $315-350$ & $220-245$ & $175-220$ & $175-205$ \\
Abaxial side & $315-345$ & $195-245$ & $395-440$ & $600-630$ & $505-575$ & $620-665$ \\
Maximum width & $110-125$ & $125-145$ & $195-205$ & $260-270$ & $270-290$ & $250-260$ \\
Diameter at rim & $80-90$ & $80-95$ & $160-170$ & $160-165$ & $150-185$ & $165-175$ \\
\hline
\end{tabular}

"frontal" aspect of the stem or higher order branches; up to $2^{\text {nd }}$ order branching observed. Division into internodes indistinct, but equivalents of internodes composed of the regular sequence: a first, basal apophysis (60-90 $\mu \mathrm{m}$ long) and its associated axillar hydrotheca, two additional, alternate hydrothecae above, and a second axillar apophysis with its associated hydrotheca. Following internode with same sequence, but its proximal apophysis on side opposite to the distal apophysis of preceding internode. Cladia leaving axis at $75-80^{\circ}$ from upper part of stem or branches; two successive cladia on same side of stem are distant of 2200-2310 $\mu \mathrm{m}$; strictly monosiphonic, alternate, up to $1 \mathrm{~cm}$ long, comprising a succession of up to 23 alternate hydrothecae. Division into internodes indistinct; equivalent of first cladial internode comparatively longer $(580-705 \mu \mathrm{m})$ than subsequent ones $(480-515 \mu \mathrm{m})$; internodes short, accommodating a single hydrotheca distally. Hydrothecae widely spaced on stem $(570-740 \mu \mathrm{m})$, less so on cladia $(470-530 \mu \mathrm{m})$; tubular, slightly curving up- and outwards, free part angled at $50^{\circ}$ to the axis of internode; stem hydrothecae slightly shifted on frontally; the two rows of cladial hydrothecae coplanar; less than half adnate on cladia, but considerably immersed into the stem internodes; free adaxial side nearly straight, adnate counterpart curved, ending basally in perisarc peg; abaxial side convex, with inflexion point in middle; aperture with three low cusps separated by shallow embayments; opercular apparatus lost. Gonothecae unknown.

\section{Remarks}

The branching pattern of the stems of G. plumularioides sp. nov. resembles that seen in some plumularioid hydroids that build three-dimensional colonies (e.g., Macrorhynchia philippina Kirchenpauer, 1872, M. allmani (Nutting, 1900), Plumularia spiralis Billard, 1911, etc.), and is consequently different from that observed in its congeners (e.g., G. amphorifera, G. sinuosa, G. nova sp. nov., see description below), which generally build planar colonies.

The regular structure of the stem internodes is also peculiar, and is only occasionally observed in the material assigned herein to G. errans, a species known for its inconstant structure of the stem (Vervoort 1993).

The shape of the hydrocladial hydrothecae resembles that of other congeners: 1) G. complexa Vervoort, 1993, but in this species the hydrothecae have an exceedingly long part free from internode; 2) G. elegans, but its hydrothecae have a conspicuously straight axis instead of being convex (compare Fig. 4C and 4H); 3) G. errans, whose hydrothecae have, however, a much longer free part (compare Fig. 4F with Fig. 4H); 4) G. intercalata Vervoort \& Watson, 2003, but its hydrothecae are huge compared to those of the new species; 5) G. stricta Vervoort, 1993, but here the hydrothecae have a much longer free part, and the cladial internodes are marked by internal, oblique perisarcal thickenings (Vervoort 1993); 6) G. tasmanica Watson \& Vervoort, 2001, but its hydrothecae are comparatively larger.

\section{Geographical distribution}

New Caledonia. 


\section{Gonaxia nova sp. nov. \\ urn:lsid:zoobank.org:act:6C6AA611-2E5C-40B9-9502-31888388A7E9}

Figs 5A-B, 6A-E; Table 2

\section{Diagnosis}

Gonaxia with either branched or unbranched, rigid, fascicled stems arising from disc-shaped hydrorhiza. Internodes slightly geniculate, comprising a latero-distal cladial apophysis with its associated hydrotheca, and two alternate hydrothecae below. Cladia alternate, composed of moderately long, geniculate internodes. Hydrothecae arranged at a wide angle to the stem; long, tubular, slightly arcuate, tumid proximally, distally tubular, adnate for $1 / 4$ their length. Gonothecae originating on both sides of the stem from below axillar hydrothecae; adnate for about half their length; erect portion tubular, ending in rather long neck region bearing the aperture distally.

\section{Etymology}

From the Latin novus, - $a$, -um (and the Grek véos), meaning new, indicating that we are dealing with a new, undescribed species.

\section{Material examined}

\section{Holotype}

MUSORSTOM 8: Stn. CP1083, a $4.2 \mathrm{~cm}$ high, unbranched colony bearing male gonothecae (MNHNIK-2012-16537).

\section{Paratypes}

MUSORSTOM 8: Stn. CP1083, eight colonies or fragments with branched or unbranched stems, of which four bear female gonothecae and range between 2.6 and $5.0 \mathrm{~cm}$ in height, while the remaining four bear male gonothecae and range between 2.8 and $3.9 \mathrm{~cm}$ in height (MNHN-IK-2012-16538).

\section{Description}

Colonies composed of branched or unbranched, thick, rigid, fascicled stems arising from rhizoid hydrorhiza firmly attached to substrate. Nodes inconspicuous, even in the monosiphonic parts, but equivalents of internodes 1580-2000 $\mu \mathrm{m}$ long, slightly geniculate, composed of a latero-distal hydrocladial apophysis with its associated hydrotheca, and two additional, alternate hydrothecae below. Hydrocladia strictly monosiphonic, arranged at approximately right angles to the stem; up to $1.2 \mathrm{~cm}$ long, nodes indistinct (60-70 $\mu \mathrm{m}$ wide); equivalents of internodes moderately long, geniculate, each carrying a hydrotheca distally; first internode comparatively longer $(1020-1240 \mu \mathrm{m})$ than subsequent ones $(590-760 \mu \mathrm{m})$; up to 20 hydrothecae per cladium. Hydrothecae long, tubular, facing outwards at nearly right angles to their corresponding internodes; slightly tumid basally, walls parallel distally; adnate for about $14^{\text {th }}$ their length; free adaxial side slightly convex proximally, then straight; abaxial wall with noticeable convexity in middle; aperture triangular in frontal view; margin with three conspicuous cusps (two latero-adaxial and one abaxial) separated by rather deep embayments; operculum composed of three triangular flaps forming a low roof. Gonothecae on both sides of the stem, originating from below axillar hydrothecae; about half adnate, strongly appressed proximally to the stem; distal half erect, tubular, ending in moderately long, tronconical collar, bearing the aperture distally (small in male, Fig. 6E; comparatively larger in female, Fig. 6D); perisarc of abaxial wall of fused part finely and densely striated (Fig. 6E-F); individual gonothecae either solitary (towards apex of stem) or fused together through auxiliary tubes given off from one or both ends of their adnate parts; in highly polysiphonic parts of stem, adnate parts of gonothecae obscured by apposition of auxiliary tubes; length of adnate part 1250-1340 $\mu \mathrm{m}\left(\delta^{\Uparrow}\right)$ and

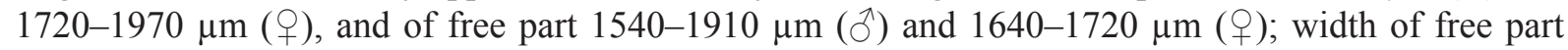




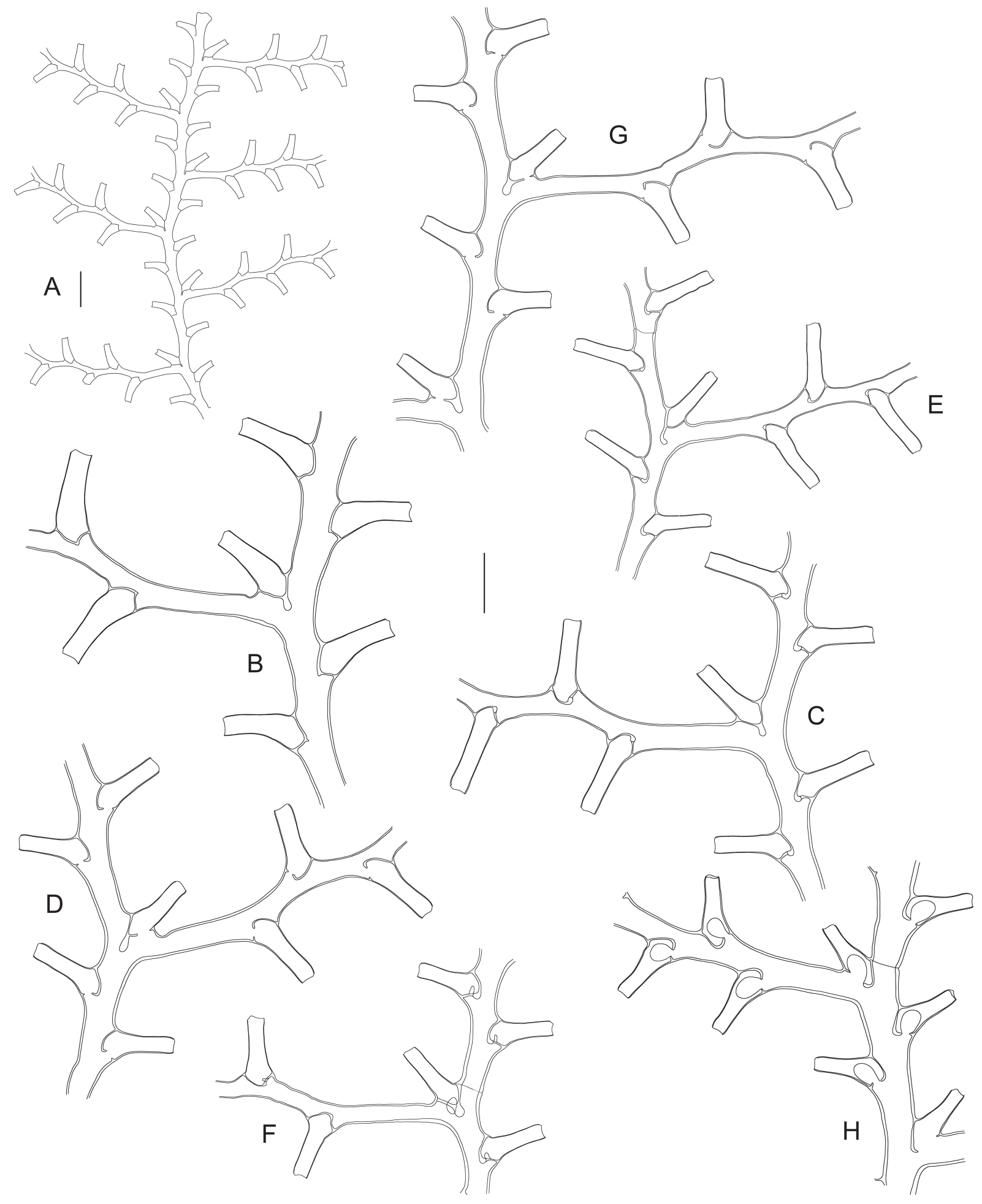

Fig. 5. - A-B. Gonaxia nova sp. nov. (MUSORSTOM 8, Stn. CP1083). A. Distalmost, monosiphonic part of a colony. B. Portion of stem with basal part of a cladium. - C-G. Gonaxia scalariformis Vervoort, 1993, portions of stems and basal parts of cladia from BIOCAL, Stn. DW46 (C = colony \#1; D = colony \#2; E = colony \#3), Stn. DW66 (F), and NORFOLK 1, Stn. DW1699 (G), showing discrete differences in shape and size. - H. Gonaxia aff. similis Vervoort, 1993 (MUSORSTOM 6, Stn. DW423), portion of stem with cladium. Scale bars: A $=1 \mathrm{~mm}$; B-H $=500 \mu \mathrm{m}$. 


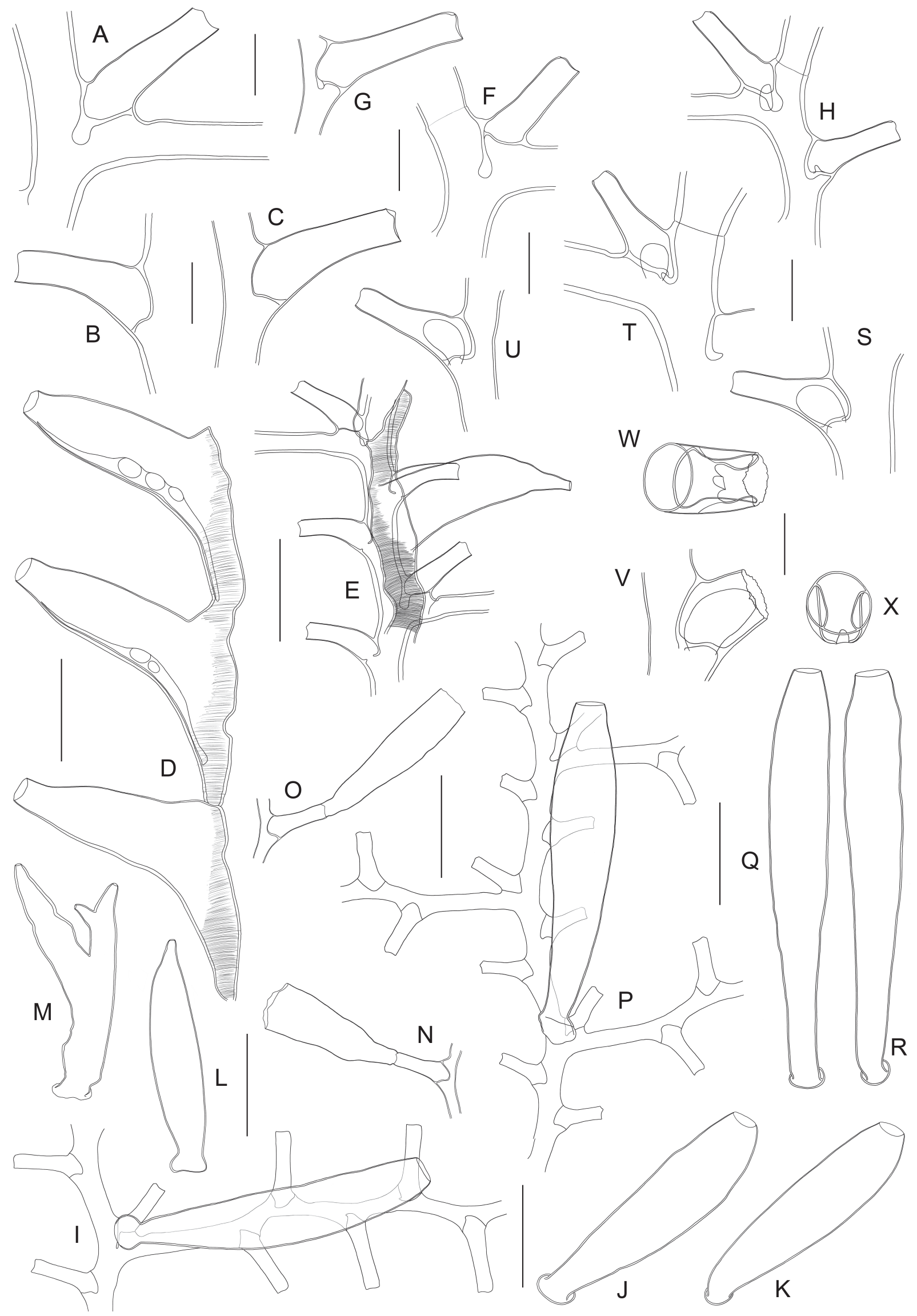


GALEA H.R., Sertulariid hydroids from the tropical western Pacific

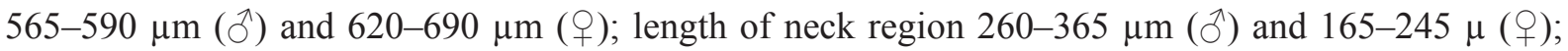
diameter at aperture $90-105 \mu \mathrm{m}\left({ }^{\Uparrow}\right)$ and $245-260 \mu \mathrm{m}($ ( $)$.

\section{Remarks}

The hydrothecae of this species resemble those of several congeners: 1) G. bulbifera Vervoort, 1993, but this species has proportionally smaller hydro- and gonothecae (about two times smaller), its hydrothecal axes are straight instead of being curved, its caulinar apophyses are conspicuously inflated, and its cladial internodes are collinear instead of being slightly geniculate; 2) G. elegans, but in this species the hydrothecae are much more closely-set, and the cladial internodes are strictly collinear (compare Fig. 5B with Fig. 4B); 3) G. perplexa Vervoort, 1993, but in this species the hydrothecae are more approximated and have straight axes, and the gonothecae are nearly fully adnate, their bodies being likely fused to each other, and their apertures are characteristically shifted outward from the stem; 4-7) G. complexa Vervoort, 1993, G. persimilis Vervoort, 1993, G. similis, and G. scalariformis, but these species are immediately distinguished through their free gonothecae, originating perpendicularly to the stems; 8) G. stricta Vervoort, 1993, but in this species the hydrothecae have straight axes and they are more approximated on cladia.

\section{Geographical distribution}

Vanuatu.

Gonaxia scalariformis Vervoort, 1993

Figs $5 \mathrm{C}-\mathrm{G}, 6 \mathrm{~F}-\mathrm{R}$

Gonaxia scalariformis Vervoort, 1993: 173, figs 31b, 32, 33c-d, 35a.

\section{Material examined}

BIOCAL: Stn. DW46, three colonies (\#1-3) slightly differing in the size of their hydrothecae: colony $\# 1$ is $3.5 \mathrm{~cm}$ high, devoid of its hydrorhiza, and bears two female gonothecae (MNHN-IK-2012-16539), colony \#2 is $2.8 \mathrm{~cm}$ high, devoid of its hydrorhiza, and bears three female gonothecae (MNHNIK-2012-16540), and colony \#3 is $2.2 \mathrm{~cm}$ high and broken in two parts, the basal one exhibiting remnants of hydrorhiza; both parts bear five male gonothecae each (MNHN-IK-2012-16541); Stn. DW66, a 1.6 $\mathrm{cm}$ high colony devoid of both its hydrorhiza and apical part, with two abortive gonothecae (MNHNIK-2012-16542); Stn. CP69, a $1.4 \mathrm{~cm}$ high colony devoid of its distalmost part, with a single female gonotheca (MNHN-IK-2012-16543).

NORFOLK 1: Stn. DW1699, a $1.7 \mathrm{~cm}$ high colony devoid of both its hydrorhiza and upper part, bearing two female gonothecae (MNHN-IK-2012-16544).

Fig. 6. (previous page) - A-E. Gonaxia nova sp. nov. (MUSORSTOM 8, Stn. CP1083). A. Axillar hydrotheca. B. Caulinar hydrotheca. C. Cladial hydrotheca. D. Female gonothecae, lateral view. E. Male gonotheca, slightly oblique view. - F-R. Gonaxia scalariformis Vervoort, 1993. F. Axillar hydrotheca (BIOCAL, Stn. DW46, colony \#1). G. Cladial hydrotheca (BIOCAL, Stn. DW46, colony \#1). H. Caulinar and axillar hydrothecae (BIOCAL, Stn. DW66). I-M. Normal gonothecae from BIOCAL, Stn. DW46 (I = colony \#1; J-K = colony \#2; L-M = colony \#3). $\mathbf{N}-\mathbf{O}$. Abortive gonotheca from BIOCAL, Stn. DW66. P-R. Normal gonothecae from BIOCAL, Stn. CP69 (P) and NORFOLK 1, Stn. DW1699 (QR). - S-X. Gonaxia aff. similis Vervoort, 1993 (MUSORSTOM 6, Stn. DW423). S. Cauline hydrotheca. T. Axillar hydrotheca. U. Cladial hydrotheca. V. Lateral view of a hydrotheca, showing diverticulum. W. Same hydrotheca viewed from above, showing minute foramen for the passage of coenosarc, and lateral diverticuli. X. Same hydrotheca in apical view, showing lateral diverticuli and basal foramen. Scale bars: A-C, F-H, S-U = $300 \mu \mathrm{m}$; D-E, I-R = $1 \mathrm{~mm}$; V-X $=200 \mu \mathrm{m}$. 


\section{Remarks}

All available specimens have lightly fascicled stems basally, and none is ramified. Although the arrangement and general shape of the hydrothecae perfectly match the description of the holotype, noticeable variations in size could be observed. Thus, the colony \#3 from sample BIOCAL, Stn. DW46 has the slenderest hydrothecae, while those from NORFOLK 1, Stn. DW1699 are the widest ones. In the sample from BIOCAL, Stn. DW66, incipient antero-dorsal diverticuli are seen in most hydrothecae (Fig. 5F). Gonothecae of both sexes are present in the available material. Although they conform to the original description, the male gonothecae in the colony \#3 from BIOCAL, Stn. DW46 are arranged on both anterior and posterior sides of the stem, and some exhibit bifid (Fig. 6M) or trifid apices. The female gonothecae from BIOCAL, Stn. DW66 are likely abortive, as they originate from within the hydrothecae (Fig. 6N-O); in addition, they are not fully formed, as their distal ends are missing; their sex is indeterminate. The female gonothecae from NORFOLK 1, Stn. DW1699 (Fig. 6Q-R) are the longest with respect to those present in the other samples.

\section{Geographical distribution}

New Caledonia and Norfolk Ridge (Vervoort 1993; present study).

Gonaxia aff. similis Vervoort, 1993

Figs $5 \mathrm{H}, 6 \mathrm{~S}-\mathrm{X}$

Gonaxia similis Vervoort, 1993: 174, figs 33e-f, 34, 36a, 39a.

\section{Material examined}

MUSORSTOM 6: Stn. DW423, a 2.7 cm high, sterile colony (MNHN-IK-2012-16545).

\section{Remarks}

The present specimen is likely part of the material in RMNH-Coel. 25839 (also from MUSORSTOM 6, Stn. DW423) studied by Vervoort (1993).

According to Vervoort, his material had gonothecae adnate to the stem (p. 174, fig. 34c), not arranged perpendicularly to it, as in the majority of samples assigned by him to G. similis. Consequently, the material in hand may belong to a separate species.

One hydrocladium in the present specimen is branched, and the secondary cladium is borne on a short, quadrangular apophysis originating from below the hydrothecal base of the first internode of a cladium.

Not mentioned by Vervoort in his sample RMNH-Coel. 25839 is the constant presence of well-developed antero-posterior diverticuli within the hydrothecae (Figs 5H, 6S-V). Such variably developed diverticuli also occur in other congeners discussed herein, viz. G. amphorifera (Fig. 3A), G. ampullacea (Fig. 3C), and G. scalariformis (Fig. 5F). In the present material, their development is considerable, and extends well on each lateral side of the hydrotheca. A frontal view of the free adaxial wall of the hydrotheca (Fig. 6W), and a frontal view of the aperture (Fig. 6X) show two empty lateral "pockets" which narrow considerably the hydrothecal lumen; the foramen for the passage of the hydranth within the hydrotheca is minute and horseshoe-shaped.

\section{Geographical distribution}

New Caledonia (Vervoort 1993; present study). 
GALEA H.R., Sertulariid hydroids from the tropical western Pacific

Genus Idiellana Cotton \& Godfrey, 1942

Idiellana pristis (Lamouroux, 1816)

Fig. 7A

Idia pristis Lamouroux, 1816: 199, pl. 5, fig. 5.

Idiellana pristis - Schuchert 2003: 175, fig. 32.

\section{Material examined}

MUSORSTOM 3: Stn. CP121, sterile colony composed of two stems, 1.7 and $3.7 \mathrm{~cm}$ high (MNHNIK-2012-16546); Stn. CP134, sterile colony composed of two stems, 1.5 and $2.7 \mathrm{~cm}$ high (MNHNIK-2012-16547).

MUSORSTOM 8: Stn. DW1021, two sterile stems, 3.5 and $5 \mathrm{~cm}$ high (MNHN-IK-2012-16548); Stn. CP1131, several sterile stems, $1.5-8.5 \mathrm{~cm}$ high (MNHN-IK-2012-16549).

TAIWAN 1: Stn. DW1, four sterile stems, 0.7-1.4 cm high, on gravel (MNHN-IK-2012-16550).

\section{Remarks}

For the latest redescription and a list of synonyms, refer to Schuchert (2003).

\section{Geographical distribution}

Circumglobal in tropical and subtropical seas (Precker \& Lawn 2010).

Genus Salacia Lamouroux, 1816

Salacia macer Vervoort \& Watson, 2003

Fig. 7B-G

Salacia macer Vervoort \& Watson, 2003: 154, figs 34g, 35a.

\section{Material examined}

BATHUS 3: Stn. DW809, single sterile stem, $2.4 \mathrm{~cm}$ high, partly damaged (several cladia missing) (MNHN-IK-2012-16551).

NORFOLK 1: Stn. DW1659, four stems 3-4.5 cm high, two of which bear female gonothecae (MNHNIK-2012-16552).

\section{Remarks}

The slender habit of these colonies, their regularly-pinnate branching pattern and their division into internodes, each of which bears a single pair of strictly opposite hydrothecae, are diagnostic (Vervoort $\&$ Watson 2003). The gonothecae, not previously described, are present in this material, and are female. They are borne on either the stem or cladia, and are arranged perpendicularly from below one hydrotheca of a pair. Urn-shaped, smooth-walled, 3280-3565 $\mu \mathrm{m}$ long and 1110-1170 $\mu \mathrm{m}$ wide, tapering basally into a short pedicel; distally truncate, aperture circular, 590-615 $\mu \mathrm{m}$ wide, borne on a short, 565-575 $\mu \mathrm{m}$ wide neck region. Possibly up to 100 oocytes per gonotheca, though their number is difficult to ascertain.

\section{Geographical distribution}

Norfolk Ridge (Vervoort \& Watson 2003; present study). 


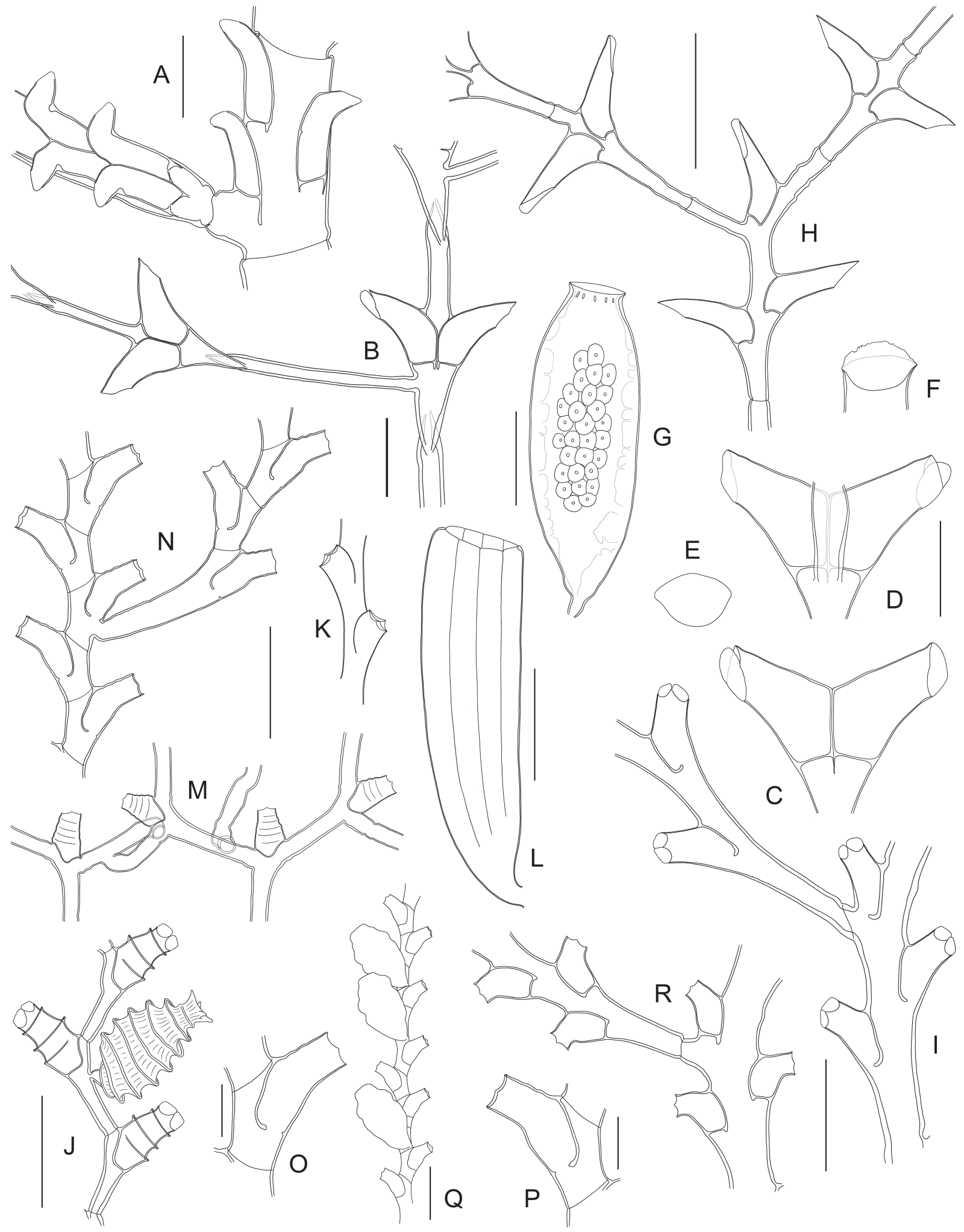

Fig. 7. (continued on next page) - A. Idiellana pristis (Lamouroux, 1816) (TAIWAN 1, Stn. DW1), stem internode and basal part of cladium. - B-G. Salacia macer Vervoort \& Watson, 2003 (NORFOLK 1, Stn. DW1659). B. Stem internode and basal part of cladium. C. Hydrothecae, frontal view. D. Same, dorsal view. E. Hydrothecal aperture, frontal view. F. Hydrothecal aperture, oblique view, showing 
Salacia sibogae Billard, 1924

Fig. $7 \mathrm{H}$

Salacia sibogae Billard, 1924: 64, fig. 1b-c.

Salacia sibogae-Schuchert 2003: 177, fig. 34

\section{Material examined}

MUSORSTOM 3: Stn. DR126, four small $(0.4-1.1 \mathrm{~cm}$ high), sterile stems on axis of dead gorgonian (MNHN-IK-2012-16553).

\section{Remarks}

A recent redescription of this species and a list of synonyms are available in Schuchert (2003).

\section{Geographical distribution}

Previosuly known from Indonesia and Japan (Schuchert 2003). The present material originates from the Philippines.

Genus Sertularella Gray, 1848

Sertularella acutidentata Billard, 1919

Fig. 7I

Sertularella acutidentata Billard, 1919: 20, figs 1e, 2.

Sertularella acutidentata acutidentata - Vervoort \& Watson 2003: 154, fig. 35b-e.

\section{Material examined}

TAIWAN 2: Stn. DW118, two infertile colonies, 7 and $8 \mathrm{~cm}$ high (MNHN-IK-2012-16554).

\section{Remarks}

For a redescription of this species, refer to Hirohito (1995). Its synonymy is given by Vervoort \& Watson (2003).

\section{Geographical distribution}

Indonesia, Japan, Philippines, New Caledonia, and north of New Zealand (Vervoort \& Watson 2003).

operculum. G. Female gonotheca. - H. Salacia sibogae Billard, 1924 (MUSORSTOM 3, Stn. DR126), portion of stem and basal part of cladium. - I. Sertularella acutidentata Billard, 1919 (TAIWAN 2, Stn. DW118), portion of stem with basal part of side branch. - J. Sertularella areyi Nutting, 1904 (BATHUS 3, Stn. CP813), portion of fertile stem. - K-L. Sertularella diaphana (Allman, 1885) (MUSORSTOM 8, Stn. CP1104). K. Two hydrothecae. L. Gonotheca. - M. Sertularella mirabilis Jäderholm, 1896 (TAIWAN 2, Stn. DW118), portion of colony. - N-Q. Sertularella novaecaledoniae Vervoort, 1993 (MUSORSTOM 4, Stn. DW221). N. Portion of stem and proximal part of a branch. O-P. Hydrothecae. Q. Portion of stem with gonothecae. - R. Sertularella quadridens (Bale, 1884) (MUSORSTOM 3, Stn. CP121), portion of stem and proximal part of a side branch. Scale bars: A-B = $500 \mu \mathrm{m} ; \mathrm{C}-\mathrm{F}=400 \mu \mathrm{m} ; \mathrm{G}-\mathrm{N}, \mathrm{Q}-\mathrm{R}=1 \mathrm{~mm} ; \mathrm{O}-\mathrm{P}=300 \mu \mathrm{m}$. 
Sertularella areyi Nutting, 1904

Fig. $7 \mathrm{~J}$

Sertularella areyi Nutting, 1904: 83, pl. 17, fig. 6.

Sertularella areyi - Vervoort \& Watson 2003: 156, fig. 35f-1.

\section{Material examined}

MUSORSTOM 4: Stn. CC174, several stems, up to $1.4 \mathrm{~cm}$ high, all but one sterile (MNHNIK-2012-16555).

BATHUS 3: Stn. CP813, fertile colonies with stems up to $1.4 \mathrm{~cm}$ high on two fragments of gorgonian (MNHN-IK-2012-16556); Stn. CP814, two infertile colonies with stems up to $1.5 \mathrm{~cm}$ high, one on dead gorgonian, the other on sponge (MNHN-IK-2012-16557).

LITHIST: Stn. DW13, small colony composed of a few sterile stems, up to $1.2 \mathrm{~cm}$ high, growing on Acryptolaria sp. (MNHN-IK-2012-16558).

BORDAU 2: Stn. DW1513, small colony composed of several sterile, up to $5 \mathrm{~mm}$ high, stems growing on G. ceramensis (MNHN-IK-2012-16559).

NORFOLK 1: Stn. DW1704, small colony composed of a restricted number of stems, some fertile and up to $1 \mathrm{~cm}$ high, epizoic on Zygophylax sp., Sertularella helenae Vervoort, 1993, and tube of coronate medusa (MNHN-IK-2012-16560).

\section{Remarks}

This very distinctive species needs no additional comments on morphology. Its synonymy, as well as a redescription, are provided by Vervoort \& Watson (2003).

\section{Geographical distribution}

Tropical and subtropical parts of the Atlantic and Indo-Pacific (Vervoort \& Watson 2003).

Sertularella diaphana (Allman, 1885)

Fig. $7 \mathrm{~K}-\mathrm{L}$

Thuiaria diaphana Allman, 1885: 145, pl. 18, figs 1-3.

Sertularella diaphana - Vervoort \& Watson 2003: 159, fig. 36g-h.

\section{Material examined}

MUSORSTOM 8: Stn. CP1104, colony composed of several fertile (male gonothecae) stems, up to $6 \mathrm{~cm}$ high, epizoic on stem of aglaopheniid hydroid (MNHN-IK-2012-16561).

\section{Remarks}

For lists of synonyms and descriptions, see Calder (1991), Vervoort (1933) and Galea (2010).

\section{Geographical distribution}

Circumglobal in tropical and subtropical seas (Vervoort \& Watson 2003). 
Fig. $7 \mathrm{M}$

Sertularella mirabilis Jäderholm, 1896: 9, pl. 2, fig. 1.

Sertularella mirabilis - Schuchert 2015: 339, fig. 13.

\section{Material examined}

TAIWAN 2: Stn. DW118, a $3.2 \mathrm{~cm}$ high, sterile colony (MNHN-IK-2012-16562).

\section{Remarks}

Hirohito (1995) provided a thorough description of this peculiar species. Its synonymy is given by Schuchert (2015).

\section{Geographical distribution}

From the South China Sea to Korea and Japan (Schuchert 2015).

Sertularella novaecaledoniae Vervoort, 1993

Fig. $7 \mathrm{~N}-\mathrm{Q}$

Sertularella novaecaledoniae Vervoort, 1993: 225, figs 50, 51aA, 52a.

\section{Material examined}

MUSORSTOM 4: Stn. DW221, a 4 cm high, fertile colony (MNHN-IK-2012-16563).

\section{Remarks}

The present material, represented by a colony with flabellate appearance, with fascicled stem and side branches divided into very short internodes, each carrying a tubular hydrotheca adnate for about half its length, conforms to the description of the type given by Vervoort (1993). The gonothecae have undulated walls, and their apical part is flattened (Fig. 7Q).

\section{Geographical distribution}

New Caledonia (present study), Norfolk Ridge (Vervoort 1993).

\section{Sertularella quadridens (Bale, 1884)}

Fig. 7R

Thuiaria quadridens Bale, 1884: 119, pl. 7, figs 5-6.

Sertularella quadridens - Schuchert 2003: 185, fig. 41.

\section{Material examined}

MUSORSTOM 3: Stn. DR117, a 18 mm high, sterile colony (MNHN-IK-2012-16564); Stn. CP121, a complete colony, $3 \mathrm{~cm}$ high, as well as four fragments, $1.4-3.2 \mathrm{~cm}$ high, all sterile (MNHNIK-2012-16565).

\section{Remarks}

For a list of synonyms and a recent redescription, see Schuchert (2003). 


\title{
Geographical distribution
}

Widely distributed throughout the tropical Indo-Pacific (Precker \& Lawn 2010).

\author{
Sertularella folliformis sp. nov. \\ urn:1sid:zoobank.org:act:7A654AE7-6B4E-465C-9F5A-1D48528466E5
}

Fig. 8A-G; Table 3

\section{Diagnosis}

Sertularella species with flabellate colonies; branching irregular; stem and branches strongly polysiphonic basally, grading to monosiphonic distally; internodes short, slightly geniculate to collinear; hydrothecae exceedingly long, tubular, curved downwards, with 8-10 broad, complete annuli and four internal, submarginal cusps. Gonothecae large, elongated-ovoid, distally truncate.

\section{Etymology}

From the Latin words follis, meaning bellows, and förma, meaning shape, with reference to the plicate condition of the hydrothecal wall, recalling the bellows of an accordion.

\section{Material examined}

\section{Holotype}

BATHUS 3: Stn. DW809, a $4.5 \times 4.5 \mathrm{~cm}$ sterile colony and four smaller fragments, three of which bear one gonotheca, and the fourth two gonothecae (MNHN-IK-2012-16566).

\section{Paratype}

BATHUS 3: Stn. DW809, a few colonies and fragments, largest one $7.5 \times 3.5 \mathrm{~cm}$, all sterile $(\mathrm{MNHN}-$ IK-2012-16567).

\section{Description}

Colonies flabellate, attaining $7.5 \mathrm{~cm}$ high, arising from rhizoid stolons firmly attached to substrate. Branching irregular, with up to $3^{\text {rd }}$ order branches arranged roughly in one plane. Stems and side branches polysiphonic, main stem reaching as much as $2 \mathrm{~mm}$ wide basally. Both stem and branches divided into internodes by slightly-marked nodes slanting in alternate directions. Internodes short, slightly geniculate to collinear, each carrying a hydrotheca in its distal half. Side branches originate laterally below the bases of stem hydrothecae; first internode comparatively longer than subsequent ones. Hydrothecae exceedingly long, tubular, slightly curved downward, adnate for $14^{\text {th }}$ or less their length, tapering imperceptibly towards aperture, walls provided with $8-10$ broad, complete annuli; margin occasionally renovated; rim provided with four short cusps separated by shallow embayments; four submarginal, intrathecal projections of perisarc, two latero-adaxial and two latero-abaxial. Gonotheca originating from axil of hydrotheca, in front and/or backside of colony; elongated-ovoid, tapering abruptly below, distally truncate, wall smooth to slightly undulate.

\section{Remarks}

The hydrothecal shape is diagnostic in this species. There are few congeners which approach this condition, viz. S. catena (Allman, 1888) and S. pseudocatena sp. nov. (Fig. 9J), but both have much shorter hydrothecae, and their transverse ribs do not extend over the abaxial wall. Three other species, namely S. helenae Vervoort, 1993 (Fig. 8H), S. paucicostata Vervoort, 1993 (Fig. 8I), and S. pseudocostata Vervoort, 1993, exhibit comparatively more prominent hydrothecal ridges. The eastern Pacific S. exilis Fraser, 1938 has isodiametric hydrothecae "regularly curved upward and then outward" (Fraser 1938), but their surface is reportedly smooth. In addition, it is "an especially diminutive species" 
GALEA H.R., Sertulariid hydroids from the tropical western Pacific

Table 3. Measurements (in $\mu \mathrm{m}$ ) of Sertularella folliformis sp. nov. and S. plicata sp. nov.

\begin{tabular}{lcc}
\hline & S. folliformis sp. nov. & S. plicata sp. nov. \\
\hline Internodes & & \\
- length (in general) & $680-865$ & $660-890$ \\
- length $\left(1^{\text {st }}\right.$ cladial internode) & $1360-2405$ & $1365-1450$ \\
- diameter at node & $325-400$ & $125-145$ \\
Hydrotheca & & \\
- free adaxial side & $1025-1235$ & $365-440$ \\
- adnate adaxial side & $375-415$ & $190-225$ \\
- abcauline side & $1170-1295$ & $450-495$ \\
- maximum width & $320-345$ & $255-275$ \\
- diameter at rim & $290-305$ & $170-180$ \\
Gonotheca & & - \\
- length & $2245-2345$ & - \\
- maximum width & $780-850$ & - \\
- apical width & $445-455$ & \\
\hline
\end{tabular}

(Calder et al. 2009). Sertularella whitei Rees \& Vervoort, 1987 also has exceedingly long, outwardlycurved hydrothecae, but their surface is entirely smooth (Rees \& Vervoort 1987).

\section{Geographical distribution}

New Caledonia.

Sertularella helenae Vervoort, 1993

Fig. $8 \mathrm{H}$

Sertularella helenae Vervoort, 1993: 218, fig. 47b-e.

\section{Material examined}

BIOCAL: Stn. DW37, several sterile stems, up to $2.6 \mathrm{~cm}$ high, and smaller fragments (MNHNIK-2012-16568); Stn. DW38, single, sterile colony $3 \mathrm{~cm}$ high and $4.7 \mathrm{~cm}$ wide (MNHN-IK-2012-16569).

BATHUS 3: Stn. CP804, a $2.5 \mathrm{~cm}$ high and $3.8 \mathrm{~cm}$ wide, sterile colony (MNHN-IK-2012-16570); Stn. CP821, a $3.4 \mathrm{~cm}$ high, sterile colony (MNHN-IK-2012-16571); Stn. DW830, four sterile colony fragments, $0.7-1.5 \mathrm{~cm}$ high (MNHN-IK-2012-16572).

NORFOLK 1: Stn. CP1719, a $4.2 \mathrm{~cm}$ high, sterile colony (MNHN-IK-2012-16573).

SALOMON 1: Stn. DW1741, two sterile colonies, 2.2 and $2.6 \mathrm{~cm}$ high (MNHN-IK-2012-16574).

\section{Remarks}

This very distinctive species needs no additional comments on morphology. For a thorough description, see Vervoort (1993). The gonothecae still remain to be discovered.

\section{Geographical distribution}

New Caledonia (Vervoort 1993; present study), Norfolk Ridge and Solomon Islands (present study). 
Sertularella paucicostata Vervoort, 1993

Fig. 8I

Sertularella paucicostata Vervoort, 1993: 227, figs 51b-f, j.

\section{Material examined}

MUSORSTOM 3: Stn. DW809, several infertile stems, some branched, up to $1.3 \mathrm{~cm}$ high, epizoic on Sertularella folliformis sp. nov. (MNHN-IK-2012-16575).

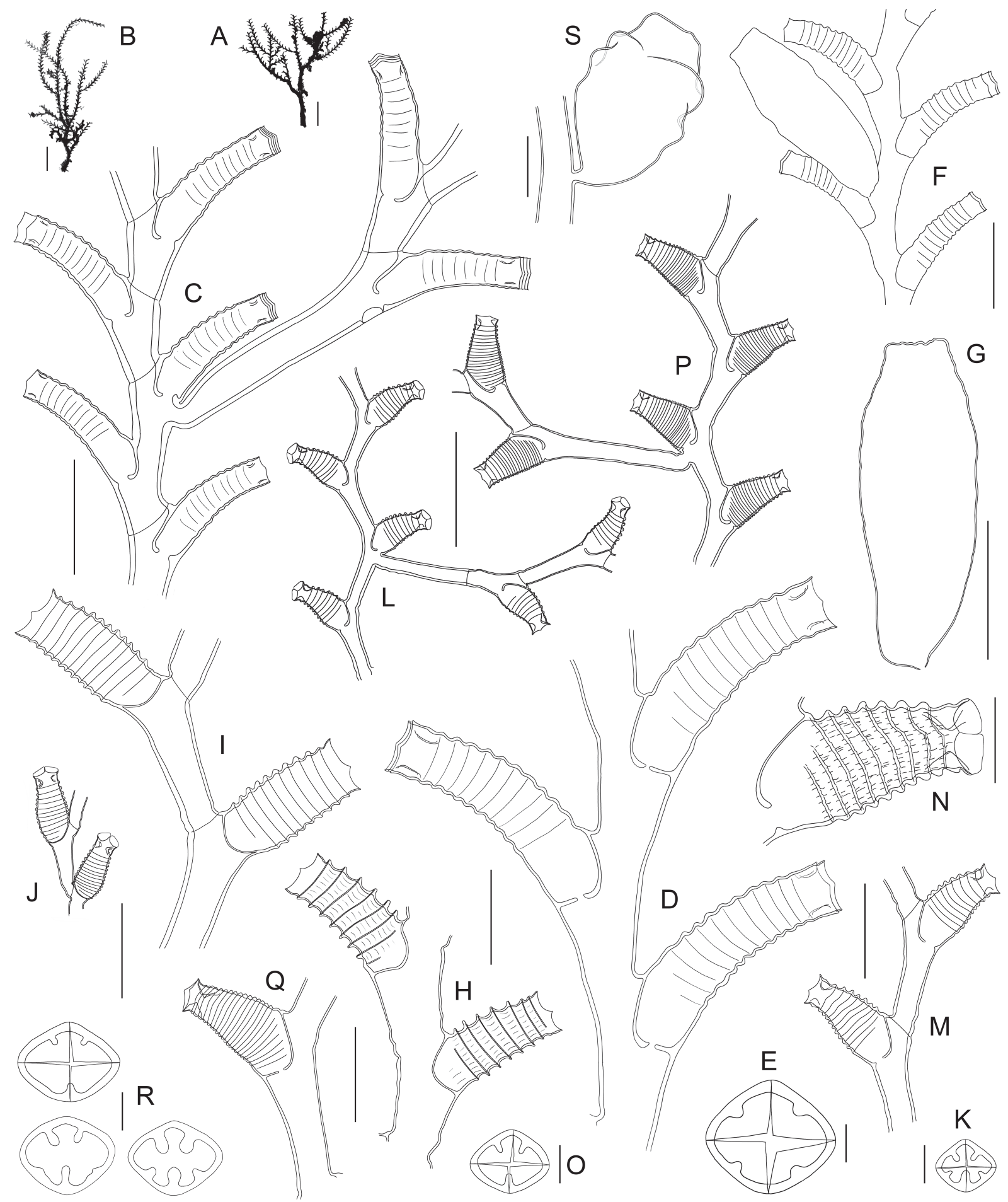


GALEA H.R., Sertulariid hydroids from the tropical western Pacific

\section{Remarks}

Surprisingly, Vervoort (1993) compared his new species with Sertularella costata Leloup, 1940, which is a much smaller and delicate hydroid (compare Fig. 8I and 8J), as illustrated by specimens of this species from the Andaman Sea, Thailand belonging to my private collection.

Sertularella costata is a rather poorly known species, with a few records around the world. Hirohito (1995) provided succinct measurements of the hydrothecae, while Calder et al. (2003) gave the first description and measurements of the gonotheca. The dimensions of the hydrothecae in the Thailand material are as follows: abcauline side 315-360 $\mu \mathrm{m}$, free adcauline side 265-280 $\mu \mathrm{m}$, adnate adcauline side $100-110 \mu \mathrm{m}$, maximum width $155-170 \mu \mathrm{m}$, diameter at aperture 130-140 $\mu \mathrm{m}$. The external wall is provided with 10-13 transverse ridges, and three internal, submarginal cusps are present within the hydrothecae (Fig. 8K). Through the size of its hydrothecae, the material from Thailand comes close to the Japanese specimens examined by Hirohito and, through the number of external ridges, it approaches that of the Galapagos specimens, which is apparently 10-11 (Calder et al. 2003: fig. 14). In contrast, about 20 ridges ornament the hydrothecal walls in material from Japan (Leloup 1940; Hirohito 1995).

In my opinion, $S$. paucicostata most closely resembles both $S$. helenae and $S$. pseudocostata Vervoort, 1993. However, unlike $S$. paucicostata, $S$. helenae forms fascicled colonies with shorter internodes, and its hydrothecae are smaller (compare Fig. $8 \mathrm{I}$ and $8 \mathrm{H}$ ) and provided with numerous perpendicular creases between the transverse ridges. According to Vervoort (1993), the hydrothecae of S. pseudocostata are comparatively larger and their outer wall has frilled ribs.

\section{Geographical distribution}

New Caledonia, Norfolk Ridge (Vervoort 1993), and the Philippines (present study).

Sertularella plicata sp. nov. urn:Isid:zoobank.org:act:5CBEB7F6-12F7-403C-AC8D-58AE01B11AC7

Fig. 8L-O; Table 3

\section{Diagnosis}

Small Sertularella with monosiphonic stems; side branches given off irregularly in one plane. Internodes moderately long and geniculate. Hydrothecae piriform, with 8-10 conspicuous, transverse ribs; aperture on short, narrow neck facing outwards; 3 or 5 internal, submarginal, lamellar cusps. Gonothecae unknown.

Fig. 8. (previous page) - A-G. Sertularella folliformis sp. nov. (BATHUS 3, Stn. DW809). A. Holotype. B. Paratype. C. Portion of stem with proximal part of a side branch. D. Successive internodes with their hydrothecae. E. Hydrothecal aperture, frontal view, showing internal cusps. F. Portion of stem with gonotheca, showing insertion site. G. Gonotheca. - H. Sertularella helenae Vervoort, 1993 (SALOMON A, Stn. DW1714), two successive internodes with their hydrothecae. - I. Sertularella paucicostata Vervoort, 1993 (BATHUS 3, Stn. DW809), two consecutive internodes with their hydrothecae, and comparison with Sertularella costata Leloup, 1940 (J-K). - L-O. Sertularella plicata sp. nov. (MUSORSTOM 3, Stn. CP121). L. Portion of stem and proximal part of a side branch. M. Two consecutive internodes with their hydrothecae. N. More detailed view of the hydrotheca, to show its wrinkled surface. O. Hydrothecal aperture in frontal view, showing internal cusps. - P-S. Sertularella aff. sinensis Jäderholm, 1896. P. Portion of stem (BATHUS 3, Stn. DW829). Q. Hydrotheca (BORDAU 2 , Stn. DW1595). R. Frontal view of three hydrothecal apertures, to show variation in the number of internal cusps. S. Gonotheca (BORDAU 2, Stn. DW1595). Scale bars: A-B = $1 \mathrm{~cm} ; \mathrm{C}, \mathrm{F}-\mathrm{G}, \mathrm{L}, \mathrm{P}=$ $1 \mathrm{~mm} ; \mathrm{D}, \mathrm{H}-\mathrm{J}, \mathrm{M}, \mathrm{Q}, \mathrm{S}=500 \mu \mathrm{m} ; \mathrm{E}, \mathrm{K}, \mathrm{O}, \mathrm{R}=100 \mu \mathrm{m} ; \mathrm{N}=200 \mu \mathrm{m}$. 


\section{Etymology}

From the Latin pluco, - $\bar{a} t u m,-\bar{a} r e$ (and the Greek $\pi \lambda \dot{\varepsilon} \chi \omega$ ), meaning "pleat, pleated, to pleat", to characterize the appearance of the external surface of the hydrothecal wall.

\section{Material examined}

Holotype

MUSORSTOM 3: Stn. CP121, colony composed of several sterile stems up to $1 \mathrm{~cm}$ high, epizoic on dead gorgonian (MNHN-IK-2012-16576).

\section{Description}

Colony composed of up to $1 \mathrm{~cm}$ high, monosiphonic stems arising from creeping, branching hydrorhiza. Basal parts of stems of varied length and ahydrothecate, perisarc smooth; above, stems divided into regular, moderately long, geniculate internodes, by means of slightly oblique nodes slanting in alternate directions; each internode with one, distal hydrotheca. Side branches arising irregularly from below the bases of stem hydrothecae and in the same plane as the stem; from one to several hydrothecae between two successive side branches; up to second order branching observed; structure identical to that of stem, except for the first internode, which is comparatively longer than following ones; distal-most, tendril-like internodes occasionally anastomose with each other or with neighboring stems. Hydrothecae swollen basally, then narrowing gradually distally to a short neck region projecting the aperture slightly outwards; adaxial side less than 1/3 adnate; walls with 8-10 conspicuous transverse ridges encircling the theca; numerous creases, perpendicular to the ridges, give the hydrotheca a wrinkled appearance; aperture rhomboidal, rim with four blunt cusps separated by shallow embayments; opercular apparatus composed of four triangular valves forming a low roof; 3 or 5 internal, submarginal, lamellar cusps (two latero-adaxial and one adaxial and, in some hydrothecae, two additional, latero-adaxial ones). Gonothecae not observed.

\section{Remarks}

Hydrothecae with such deep, transverse ridges are present in a number of congeners, but several distinctive features allow their separation from the new species: 1) S. areyi Nutting, 1904, but its hydrothecae are provided with only 2-3 transverse ridges (Fig. 7J); 2) S. costata Leloup, 1940 is a much smaller hydroid (compare Fig. 8J and 8M); 3) S. crenulata Nutting, 1905 possesses a considerable number of closely-set, transverse ridges, and its hydrothecae are tronconical (Vervoort 1993); 4-6) S. helenae Vervoort, 1993 (Fig. 8H), S. paucicostata Vervoort, 1993 (Fig. 8I) and S. pseudocostata Vervoort, 1993, but their hydrothecae are larger and more tubular; 7) S. fraseri Galea, 2010 is a more delicate hydroid and its hydrothecae are provided with fewer ridges; 8) S. quadrata Nutting, 1895 has densely-striated, exceedingly long and tubular hydrothecae, with characteristically squared cross-section (Nutting 1904); 9) the hydrothecae of $S$. sinensis Jäderholm, 1896 are only half adnate, and the number of ridges they carry reaches as many as 15 in the northern hemisphere (Naumov 1969); 10) S. striata Stechow, 1923, but in this species the internodes are comparatively shorter, almost collinear, and the hydrothecae are less fusiform and only about half adnate (Millard 1964).

\section{Geographical distribution}

Philippines.

Sertularella aff. sinensis Jäderholm, 1896

Fig. 8P-S; Table 4

Sertularella sinensis Jäderholm, 1896: 11, pl. 2, figs 2-3.

Sertularella sinensis - Vervoort \& Watson 2003: 177, fig. 41d-h. 
GALEA H.R., Sertulariid hydroids from the tropical western Pacific

Table 4. Measurements (in $\mu \mathrm{m}$ ) of Sertularella sinensis Jäderholm, 1896 from various sources.

\begin{tabular}{lccccc}
\hline & Present study & Naumov (1969) & $\begin{array}{c}\text { Vervoort (1993) } \\
\text { (CHALCAL 2, } \\
\text { Stn. DW80) }\end{array}$ & $\begin{array}{c}\text { Vervoort \& Watson (2003) } \\
\text { K825, slide 2270) }\end{array}$ & $\begin{array}{c}\text { (NMNZ BS437, } \\
\text { slide 2977) }\end{array}$ \\
\hline Internode & & - & - & - \\
- length & & - & - & - \\
- diameter at node & $180-215$ & - & & & - \\
Hydrotheca & & & & & \\
- free adaxial side & $480-540$ & $230-270$ & $250-310$ & $345-390$ & $395-425$ \\
- adnate adaxial side & $315-335$ & $250-270$ & $265-310$ & $345-375$ & $280-360$ \\
- abcauline side & $555-590$ & $350-370$ & $295-355$ & $425-460$ & $420-430$ \\
- maximum width & $335-360$ & - & $250-275$ & $310-330$ & $280-295$ \\
- diameter at aperture & $205-220$ & $150-170$ & $170-185$ & $145-165$ & $195-215$ \\
- number of ridges & $19-21$ & $11-15$ & $10-12$ & $16-20$ & ca 18 \\
\hline
\end{tabular}

\section{Material examined}

BATHUS 3: Stn. DW829, a sterile, polysiphonic, flabellate colony $3 \mathrm{~cm}$ high and $3.8 \mathrm{~cm}$ wide, broken off from its $2.3 \mathrm{~cm}$ long basal part (MNHN-IK-2012-16577).

BORDAU 2: Stn. DW1595, a single fertile stem, $6.7 \mathrm{~cm}$ high, polysiphonic basally, with only two side branches left, one of which is incomplete (MNHN-IK-2012-16578).

\section{Remarks}

The specimen from BORDAU 2 comprises a tall, erect, straight stem with only two side branches left, while numerous lateral apophyses indicate the presence of pre-existent branches. The upper part of the specimen from BATHUS 3 is flabellate, and this structure most probably arose upon the breakage of the apical part of the initial stem and the subsequent profuse development of several distal side branches, which divided up to four times. Though of different appearance, both specimens bear hydrothecae of the same shape and size, and are believed to be conspecific.

The identification of the present material is provisional, owing to multiple discrepancies exhibited by the specimens from a wide geographical area assigned to $S$. sinensis by various authors. Among the points of difference, the following ones are noteworthy: 1) the habit of the colonies is apparently strictly monosiphonic in the material from the northern hemisphere (Hirohito 1995), and polysiphonic in that from the southern one (Vervoort 1993; Vervoort \& Watson 2003; present study); 2) the shape of the hydrothecae illustrated in the literature varies from decidedly compressed longitudinally in their free part (Jäderholm 1896; Rho \& Chang 1974; Hirohito 1995) to "normally" shaped (Vervoort \& Watson 2003); 3) the number of transverse ridges accounts from 6-8 (Hirohito 1983) to 11-15 (Naumov 1969), and to as many as 19-21 (present material); 4) the dimensions of the hydrothecae exhibit a wide range of variation, as exemplified in Table $4 ; 5)$ the number of transverse ridges at the surface of the gonothecal wall varies from 5-6 (Vervoort \& Watson 2003), to ca 8 (Hirohito 1995), and to ca 14 (Jäderholm 1896: pl. 2, fig. 3); 6) the number of apical projections of the gonotheca reported, for instance, is either 4 (Jäderholm 1896; Hirohito 1995) or 8 (Vervoort \& Watson 2003); 7) small gonothecae $(750-800 \times 550$ $700 \mu \mathrm{m})$ were reported by Hirohito (1995), while comparatively larger ones (1720-1935 × 1230-1280 $\mu \mathrm{m})$ occurred in the material studied by Vervoort \& Watson (2003).

The available data suggest that we are possibly dealing with at least two sibling species: the northern hemisphere form is apparently monosiphonic in habit, the free parts of their hydrothecae are 
characteristically compressed longitudinally, the number of annulations they carry is low (not exceeding 15), and their gonothecae are small and provided with 4 apical projections; conversely, the specimens from the southern hemisphere are represented by colonies with fascicled stems and branches, the hydrothecae are "normally" shaped, the number of annulations they carry may reach as many as 21 , their gonothecae are comparatively larger, and their apices are provided with 8 projections.

In addition, the present material comes closer to that from New Zealand (Vervoort \& Watson 2003), judging by the size and number of ribs of the hydrothecae, than to the New Caledonian one (Vervoort 1993), which have smaller hydrothecae, with a lesser number of transverse ridges (see Table 4).

The gonotheca depicted in Fig. 8S is likely immature, owing to its apparently incomplete rings and flattened apical part, and originates from an auxiliary tube running up the main stem of the colony from BORDAU 2, similarly to some gonothecae examined by Vervoort \&Watson (2003).

\section{Geographical distribution}

Sertularella sinensis sensu stricto occurs from China (Jäderholm 1896) to the Sea of Okhotsk (Naumov 1969). Additional material, possibly not conspecific, was recorded from New Caledonia (Vervoort 1993; present study), Tonga (present study), and New Zealand (Vervoort \& Watson 2003).

\section{Sertularella cf. anguina Vervoort, 1993}

Fig. 9A; Table 5

Sertularella anguina Vervoort, 1993: 198, figs 40b-d, 41a-b.

\section{Material examined}

NORFOLK 1: Stn. DW1722, a sterile, unbranched stem, $3 \mathrm{~cm}$ high (MNHN-IK-2012-16579).

\section{Remarks}

This lightly fascicled stem (only basally), divided into moderately long, slender, geniculate internodes, each carrying distally an exceedingly long, slender hydrotheca with tapering walls and five internal, submarginal cusps (two latero-adaxial, one abaxial, and two latero-abaxial), fits the diagnosis of $S$. anguina given by Vervoort (1993). This author gave no precise information on the exact number of internal projections of the perisarc, but assumed that four may have been present in his material, possibly two latero-adaxial and two latero-abaxial. The fifth, strictly abaxial cusp observed in the present material is only visible when the hydrothecal apertures are seen frontally, but not laterally. Although the measurements between the material in hand and the holotype appear similar (Table 5), certain differences (as the width of the hydrotheca) may be attributed to the fact that the former was measured in water, while the latter is a microslide preparation that suffered a certain degree of shrinkage.

\section{Geographical distribution}

New Caledonia (Vervoort 1993) and Norfolk ridge (present study).

\section{Sertularella cf. bipectinata Vervoort, 1993}

Fig. 9B-C; Table 5

Sertularella bipectinata Vervoort, 1993: 207, figs 43c-e, 44.

\section{Material examined}

BATHUS 3: Stn. DW809: a $2.2 \mathrm{~cm}$ high, sterile, lightly fascicled (a couple of accessory tubes) stem, provided with two short side branches (MNHN-IK-2012-16580). 
GALEA H.R., Sertulariid hydroids from the tropical western Pacific

Table 5. Measurements (in $\mu \mathrm{m}$ ) of Sertularella cf. anguina Vervoort, 1993, S. cf. bipectinata Vervoort, 1993, and S. leiocarpoides Vervoort, 1993, and comparisons with their respective holotypes (second column for each species).

\begin{tabular}{|c|c|c|c|c|c|c|}
\hline & \multicolumn{2}{|c|}{ S. cf. anguina Vervoort, 1993} & \multicolumn{2}{|c|}{$\begin{array}{l}\text { S. cf. bipectinata } \\
\text { Vervoort, } 1993\end{array}$} & \multicolumn{2}{|c|}{$\begin{array}{l}\text { S. leiocarpoides } \\
\text { Vervoort, } 1993\end{array}$} \\
\hline & $\begin{array}{l}\text { Present study: } \\
\text { NORFOLK 1, } \\
\text { Stn. DW1722 }\end{array}$ & $\begin{array}{c}\text { Vervoort (1993): } \\
\text { MUSORSTOM } \\
\text { 6, Stn. CP464 }\end{array}$ & $\begin{array}{l}\text { Present study: } \\
\text { BATHUS 3, } \\
\text { Stn. DW809 }\end{array}$ & $\begin{array}{c}\text { Vervoort } \\
\text { (1993): } \\
\text { BIOCAL, Stn. } \\
\text { DW36 }\end{array}$ & $\begin{array}{l}\text { Present study: } \\
\text { BATHUS 3, } \\
\text { Stn. DW829 }\end{array}$ & $\begin{array}{c}\text { Vervoort (1993): } \\
\text { MUSORSTOM } \\
\text { 4, Stn. DW212 }\end{array}$ \\
\hline \multicolumn{7}{|l|}{ Internode } \\
\hline - length & $830-1200$ & $755-850$ & $1050-1110$ & $1150-1260$ & $755-1025$ & $870-1040$ \\
\hline - diam. at node & $255-310$ & $175-205$ & $325-355$ & $435-455$ & $300-340$ & $280-305$ \\
\hline \multicolumn{7}{|l|}{ Hydrotheca } \\
\hline - free adax. side & $840-900$ & $760-845$ & $1110-1170$ & $1000-1065$ & $680-765$ & $695-735$ \\
\hline - adn. adax. wall & $305-340$ & $235-245$ & $380-390$ & $450-520$ & $395-430$ & $410-435$ \\
\hline - abaxial wall & $925-1010$ & $890-935$ & $1245-1285$ & $1195-1300$ & $900-950$ & $870-910$ \\
\hline - max. width & $300-315$ & $235-245$ & $375-390$ & $410-435$ & $395-420$ & $390-410$ \\
\hline - diameter at rim & $210-245$ & $150-170$ & $260-270$ & $260-265$ & $300-310$ & $280-305$ \\
\hline \multicolumn{7}{|l|}{ Gonotheca } \\
\hline - length & - & - & - & - & ca 2955 & $3100-3255$ \\
\hline - max. width & - & - & - & - & ca 1055 & $1000-1020$ \\
\hline - apical width & - & - & - & - & ca 425 & - \\
\hline
\end{tabular}

\section{Remarks}

The present material, although similar to that assigned above to $S$. aff. anguina Vervoort, 1993, differs from it through its comparatively thicker internodes, a more reduced ratio of internode length/hydrothecal depth, and the comparatively larger size of its hydrothecae (Table 5). These features, in combination with the presence of three internal, submarginal cusps (two latero-adaxial and one abaxial), also reported by Vervoort (1993), suggest that it may belong to S. bipectinata, and this identification should be regarded as provisional in the absence of fertile material.

\section{Geographical distribution}

New Caledonia (present study), Norfolk Ridge (Vervoort 1993).

Sertularella leiocarpoides Vervoort, 1993

Figs 9D-G, 10A; Table 5

Sertularella leiocarpoides Vervoort, 1993: 223, fig. 49.

\section{Material examined}

BATHUS 2: Stn. CP737, a $5 \mathrm{~cm}$ high, sterile colony devoid of hydrorhiza (MNHN-IK-2012-16581).

BATHUS 3: Stn. DW829, a 3.5 cm high colony fragment bearing one gonotheca (MNHN-IK-2012-16582); Stn. DW830, a $5 \mathrm{~cm}$ high and $7.5 \mathrm{~cm}$ wide sterile colony (MNHN-IK-2012-16583).

SALOMON 1: Stn. DW1741, a $2 \mathrm{~cm}$ high, sterile colony (MNHN-IK-2012-16584).

\section{Remarks}

The four available specimens were compared to a colony of Sertularella leiocarpa (Allman, 1888) from Inaccessible Island (see Galea 2015b). Portions of three of them are illustrated altogether with $S$. 


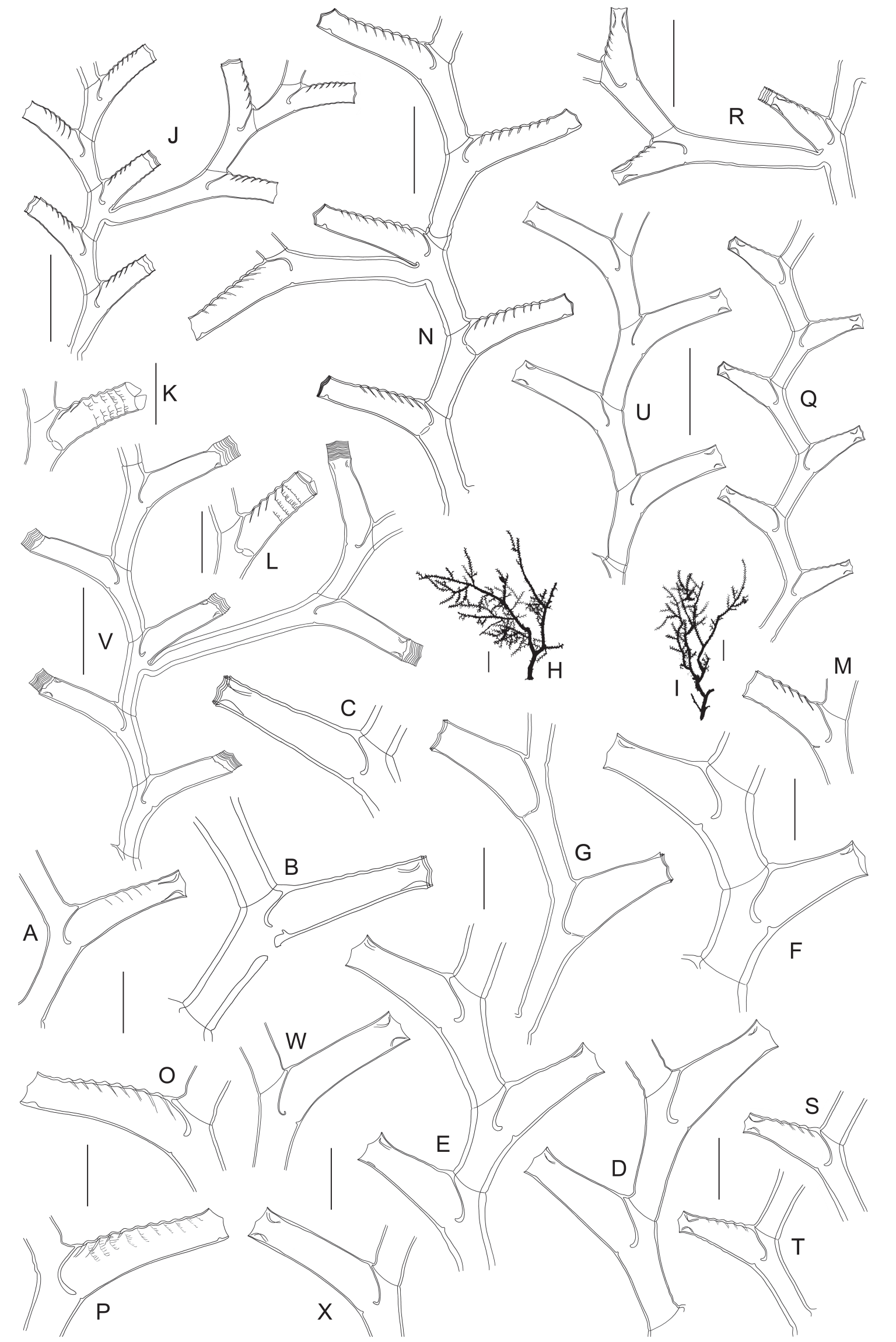


GALEA H.R., Sertulariid hydroids from the tropical western Pacific

leiocarpa, so as to show their specific differences (compare Fig. 5D-F and 5G). As already noted by Vervoort (1993), the internodes are thick, short and geniculate in S. leiocarpoides, and comparatively more slender, longer, and less geniculate in $S$. leiocarpa. In addition, the hydrothecae of Vervoort's species have the adaxial cusps characteristically upturned, and there are generally also two inconspicuous latero-adaxial, internal, submarginal projections of the perisarc and, occasionally, a third one, on the abaxial side.

\section{Geographical distribution}

New Caledonia (Vervoort 1993; present study), Solomon Islands (present study).

Sertularella pseudocatena $\mathrm{sp}$. nov. urn:1sid:zoobank.org:act:3395EF3F-3DFF-489B-AB25-B4E2A58F8F7C

Figs 9H-M, 10B-C; Table 6

Sertularella catena - Vervoort 1993: 210, fig. 45a-c [not Sertularella catena (Allman, 1888)].

\section{Diagnosis}

Flabellate colonies with highly polysiphonic stems and branches; branching irregular, given off roughly in one plane; internodes rather short; hydrothecae long, tubular, almost straight; free adaxial wall with 5-7 transverse ridges extending almost to abaxial wall; gonotheca sac-shaped, with 1-3 broad, transverse ridges and $2-5$ inconspicuous apical projections.

\section{Etymology}

The specific epithet results from the word-forming element pseudo- (derived from the Ancient Greek $\psi \varepsilon v \delta \dot{\eta} \varsigma$, pseudếs), meaning false, in appearance only, or resembling, and catena, the name of a species created by Allman (1888), suggesting that the new species superficially resembles $S$. catena.

\section{Material examined}

\section{Holotype}

BATHUS 3: Stn. DW809, single flabellate colony ca $6.5 \times 6.5 \mathrm{~cm}$, as well as three fragments from it, two of which bearing one gonotheca, while the third one carries two gonothecae (MNHN-IK-2012-16585).

\section{Paratype}

BATHUS 3: Stn. DW809, several colonies up to $8.5 \mathrm{~cm}$ high, as well as numerous smaller fragments (MNHN-IK-2012-16586).

Fig. 9. (previous page) - A. Sertularella cf. anguina Vervoort, 1993 (NORFOLK 1, Stn. DW1722), hydrotheca. - B-C. Sertularella cf. bipectinata Vervoort, 1993 (BATHUS 3, DW809), two hydrothecae. - D-F. Sertularella leiocarpoides Vervoort, 1993, three hydrothecae (D = BATHUS 2, Stn. CP737; $\mathrm{E}=$ BATHUS 3, Stn. DW829; F = Stn. DW829), and comparison with Sertularella leiocarpa (Allman, 1888) (G) from Inaccessible Island. - H-M. Sertularella pseudocatena sp. nov. (BATHUS 3, Stn. DW809). H. Holotype. I. Paratype. J. Portion of stem with side branch. K-M. Three hydrothecae. N-P. Sertularella splendida sp. nov. (BATHUS 3, Stn. DW809). N. Portion of stem and proximal part of a side branch. O-P. Two hydrothecae. - Q-T. Sertularella tronconica sp. nov. Q. Portion of side branch (NORFOLK 1, Stn. DW1704). R. Portion of stem and proximal part of a side branch (BATHUS 3, Stn. DW809). S-T. Two hydrothecae (NORFOLK 1, Stn. DW1704). - U-X. Sertularella tubulosa sp. nov. (BATHUS 3, Stn. DW810). U. Distal portion of stem. V. Portion of stem and proximal part of side branch. W-X. Two hydrothecae. Scale bars: A-G, K-M, O-P, S-T, W-X = $500 \mu \mathrm{m} ; \mathrm{J}, \mathrm{N}, \mathrm{Q}-\mathrm{R}, \mathrm{U}-\mathrm{V}=$ $1 \mathrm{~mm} ; \mathrm{H}-\mathrm{I}=1 \mathrm{~cm}$. 
Table 6. Measurements (in $\mu \mathrm{m}$ ) of four new species of Sertularella discussed herein.

\begin{tabular}{|c|c|c|c|c|c|}
\hline & \multirow{2}{*}{$\begin{array}{c}\text { S. pseudocatena } \\
\text { sp. nov. } \\
\text { (BATHUS 3, } \\
\text { Stn. DW809) }\end{array}$} & \multirow{2}{*}{$\begin{array}{l}\text { S. splendida } \\
\text { sp. nov. } \\
\text { (BATHUS 3, } \\
\text { Stn. DW809) }\end{array}$} & \multicolumn{2}{|c|}{ S. tronconica sp. nov. } & \multirow{2}{*}{$\begin{array}{l}\text { S. tubulosa } \\
\text { sp. nov. } \\
\text { (BATHUS 3, } \\
\text { Stn. DW810) }\end{array}$} \\
\hline & & & $\begin{array}{l}\text { (NORFOLK 1, } \\
\text { Stn. DW1704) }\end{array}$ & $\begin{array}{l}\text { (BATHUS 3, } \\
\text { Stn. DW809) }\end{array}$ & \\
\hline \multicolumn{6}{|l|}{ Internodes } \\
\hline - length (in general) & $495-680$ & $965-1260$ & $660-825$ & $620-890$ & $825-990$ \\
\hline - length ( $1^{\text {st }}$ cladial internode $)$ & $1135-1395$ & ca 1730 & - & $1260-1630$ & ca 2240 \\
\hline - diameter at node & $225-290$ & $335-365$ & $220-240$ & $195-245$ & $275-315$ \\
\hline \multicolumn{6}{|l|}{ Hydrotheca } \\
\hline - free adaxial side & $560-635$ & $1050-1170$ & $565-605$ & $445-480$ & $900-1050$ \\
\hline - adnate adaxial side & $295-330$ & $325-410$ & $300-315$ & $290-355$ & $350-420$ \\
\hline - abcauline side & $705-740$ & $1170-1320$ & $660-690$ & $585-660$ & $1125-1170$ \\
\hline - maximum width & $270-290$ & $400-410$ & $295-310$ & $265-300$ & $315-350$ \\
\hline - diameter at rim & $240-255$ & $280-300$ & $170-185$ & $150-160$ & $275-290$ \\
\hline \multicolumn{6}{|l|}{ Gonotheca } \\
\hline - length & $1235-1445$ & - & ca 2135 & - & - \\
\hline - maximum width & $615-765$ & - & ca 925 & - & - \\
\hline - apical width & $345-395$ & - & - & - & - \\
\hline
\end{tabular}

\section{Description}

Colonies flabellate, up to $8.5 \mathrm{~cm}$ high, of rigid appearance, though rather brittle upon manipulation, as demonstrated by the highly fragmented condition of the present material. Stolon rhizoid, firmly attached to substrate. Stems strongly fascicled, attaining up to $3 \mathrm{~mm}$ wide basally; irregularly ramified (up to $5^{\text {th }}$ order branches, but possibly more in living specimens), branches roughly coplanar. Perisarc moderately thick, straw colored. Basal parts of side branches also polysiphonic, thinning out to monosiphonic distally. Main tube of both stems and side branches divided into rather short internodes by means of oblique nodes slanting in alternate directions; internodes distinctly geniculate, each carrying a hydrotheca distally. Side branches arising laterally from below the bases of hydrothecae; first internode longer than subsequent ones. Hydrothecae alternate, long, tubular, given off at about $25^{\circ}$ with axis of internode; free adaxial side with 5-7 conspicuous wrinkles reaching abaxial wall, which appears undulated; wrinkles backward-oriented at site of origin on adaxial wall (Fig. 9L-M), becoming transverse towards abaxial wall (Fig. 9K); base of hydrotheca with an incomplete septum, leaving a large foramen for the passage of hydranth; margin generally renovated several times, provided with four short cusps separated by shallow embayments; aperture quadrangular in frontal view; no internal, submarginal projections of perisarc. Coenosarc poorly preserved, tentacle number could not be ascertained. Gonothecae (only 4 seen) arising from an internode on side opposite hydrotheca, midway between base of theca and proximal node; thick-walled, with 2-3 transverse "ribs", aperture on well-formed neck, enclosed by filmy perisarc; 2-5 blunt, inconspicuous projections around aperture; body tapering below into indistinct pedicel; sex could not be ascertained.

\section{Remarks}

Vervoort (1993) assigned his infertile material from New Caledonia to S. catena (Allman, 1888), a species known only from the Caribbean region, on the account of morphological similarities in the "structure and shape of the hydrothecae". Unfortunately, Vervoort did not provide any updated illustrations of Allman's holotype to facilitate a comparison with the New Caledonian specimens.

However, though of nearly similar size, the appearance of the holotype of $S$. catena, illustrated by Allman (1888: pl. 27, fig. 2), differs radically from the silhouettes of the colonies from New Caledonia (Fig. 9H-I), in having a definite main stem and a comparatively more sparing branching pattern. In 
GALEA H.R., Sertulariid hydroids from the tropical western Pacific

addition, unlike the strictly tubular hydrothecae observed in the material in hand (Fig. 9J-M), those of S. catena appear "subcylindrical" (especially on the adaxial side) and "narrowed slightly at each end" (Nutting 1904: pl. 15, fig. 3); this is also evident from Allman's illustration (1888: pl. 27, fig. 2a).

The present material bears several gonothecae and, consequently, allows a much more reliable distinction from Allman's species to be made. Unlike the transversely ribbed gonothecae observed here, those of S. catena are reportedly "elongate ovate, destitute of annulation, with a small terminal, bicuspate orifice" (Allman 1888). Upon a reexamination of the type, Nutting (1904) added the following: "Gonangia [...] large, terete in form, orifice terminal, small, armed with two shallow processes or teeth" (Nutting 1904). Although their surface was originally illustrated as totally smooth (Allman 1888: pl. 28, fig. 2a), Nutting (1904) added that "There is apparently a series of very shallow rugosities or annulations on the distal portion of the gonangia" (illustrated in his pl. 15, fig. 3). This is corroborated by Vervoort's observation, which confirms the existence "at the apical third" of the gonotheca of "two indistinct furrows", though he states that "there is no funnel and no distinct opening".

In addition, the length of the gonothecae in the present material encompasses that of a whole internode with its associated hydrotheca, measured from the proximal node to the hydrothecal aperture. In contrast, the gonothecae of $S$. catena are comparatively bigger: in Allman's figure (1888: pl. 28, fig. 2a), the gonotheca is illustrated being as long as three successive internodes, while in Nutting's figure (1904: pl. 15 , fig. 3 ) is encompasses the length of 2.5 internodes.

Taken together, the appearance of the colonies, with their profuse branching pattern, the perfectly tubular and slightly curved hydrothecae marked with conspicuous furrows at their surface, as well as the comparatively smaller and transversely ribbed gonotheca, suggest that we are dealing with a species distinct from $S$. catena. Additional, geographical considerations support this view.

\section{Geographical distribution}

New Caledonia (Vervoort 1993; present study).

Sertularella splendida $\mathrm{sp}$. nov. urn:1sid:zoobank.org:act:900C4D1A-64A7-402E-B695-3BF396F18579

Fig. 9N-P; Table 6

\section{Diagnosis}

Sertularella with lightly fascicled, irregularly and sparsely branched stems; internodes moderately long, geniculate; hydrothecae exceedingly long, gradually narrowing slightly from base to aperture, adnate for $1 / 4$ or less, free adaxial side with 7-9 transverse ridges, an intrathecal cusp abaxially. Gonothecae unknown.

\section{Etymology}

From the Latin adjective splendìdo, - $a$, -um (splendeo), originally meaning brilliant, dazzling, or glowing, but subsequently retained as "splendid" or "magnificent" in modern usage, to denote the beautiful appearance displayed by this species.

\section{Material examined}

\section{Holotype}

BATHUS 3: Stn. DW809, a $23 \mathrm{~mm}$ high, sterile stem fragment devoid of its basal part, but carrying a short, distally broken side branch; an accessory tube on the stem (MNHN-IK-2012-16587). 
Paratypes

BATHUS 3: Stn. DW809, four sterile stems or fragments, 7-14 mm high; side branches occur in two specimens; accessory tubes also present in two specimens (MNHN-IK-2012-16588).

\section{Description}

Colonies up to $23 \mathrm{~mm}$ high, arising from rhizoid stolon firmly attached to substrate; stems either lightly fascicled basally (with 1-2 auxiliary tubes) or monosiphonic; basal part of varied length, ahydrothecate, with smooth, thick perisarc; above, stem divided into regular internodes by means of slightly oblique nodes sloping in alternate directions; internodes geniculate, moderately long, widening gradually towards distal end, where they bear a hydrotheca. Side branches, when present, originating from below a stem hydrotheca, either laterally, or slightly in front of colony; first internode longer than subsequent ones, constricted basally at insertion on stem; remainder of side branch with same structure as stem. Hydrothecae alternate on stem and branches, originating at an angle of 50-60 with the internode; exceedingly long, slightly curving downward proximally and upward distally, tapering gradually, though rather imperceptibly, towards aperture; adaxial wall $1 / 4$ to $1 / 5$ adnate to internode; free part with 7-9 prominent grooves; abaxial wall slightly sigmoid; basal foramen wide; distal end of hydrotheca slightly upturned; margin with four short, triangular cusps separated by shallow embayments; aperture quadrate in frontal view; an intrathecal cusp abaxially. Gonothecae absent.

\section{Remarks}

A careful search of the relevant literature reveals no other Sertularella species which approaches the present hydroid in the morphology of its hydrothecae.

\section{Geographical distribution}

New Caledonia.

\section{Sertularella tronconica sp. nov. urn:1sid:zoobank.org:act:CC79A536-B897-4CA4-9C85-DB835908E5BE} Figs 9Q-T, 10D; Table 6

\section{Diagnosis}

Sertularella with lightly fascicled, irregularly and sparsely branched stems; colonies coplanar; internodes moderately long, geniculate; hydrothecae tronconical, adnate for $1 / 3$ their length; adaxial wall with 4-5 transverse ridges; 5 prominent intrathecal, submarginal cusps; gonotheca large, transversely ridged adaxially.

\section{Eymology}

From the Latin words, truncāre, meaning to truncate, and cōnus (also $\chi \omega v o \varsigma$ in Greek), meaning cone, to characterize the shape of the hydrotheca.

\section{Material examined}

\section{Holotype}

NORFOLK 1: Stn. DW1704, single, unbranched colony, $2 \mathrm{~cm}$ high, devoid of its hydrorhiza, but bearing a basal accessory tube running up the stem; a female gonotheca present (several large oocytes still noticeable inside) (MNHN-IK-2012-16589).

\section{Paratypes}

BATHUS 3: Stn. DW809, several sterile stems and fragments, up to $1.4 \mathrm{~cm}$ high, some branched and some with lightly fascicled stems (MNHN-IK-2012-16590). 


\section{Description}

Colonies up to $2 \mathrm{~cm}$ high, arising from creeping (young colonies) to rhizoid (adult colonies) hydrorhiza, firmly attached to substrate. Basal part of stem of varied length, ahydrothecate, bearing a reduced number of accessory tubes; perisarc thick and smooth. Remainder of stem divided into regular internodes by means of oblique constrictions of the perisarc slanting in alternate directions. Internodes moderately long, width increasing imperceptibly towards distal ends, so as to accommodate the basal part of a hydrotheca. Branching scarce and irregular, in one plane, with up to $2^{\text {nd }}$ order branches observed; side branches originating laterally from below the base of a stem hydrotheca; first internode comparatively longer than subsequent ones, constricted basally at insertion on stem; remainder of side branches with similar structure as the stem. Hydrothecae arranged alternately at an angle of $35-40^{\circ}$ with the internode; moderately long, tronconical, widening slightly below aperture; adaxial wall adnate for about $1 / 3$ its length; free part with 4-5 transverse, though incomplete, ridges, not reaching abaxial side, running parallel to adnate side of adaxial wall; abaxial wall nearly straight; margin occasionally renovated; aperture quadrate in frontal view, bearing 4 short cusps separated by shallow embayments; five prominent, submarginal, intrathecal cusps: two latero-adaxial, two latero-abaxial, and one abaxial. Gonothecae originating from the internode, on side opposite hydrotheca, midway between its base and proximal node; large, transversely ribbed; a short, distal neck; aperture large, surrounded by 3-4 almost imperceptible, blunt cusps; a few large oocytes noticeable by transparency.

\section{Remarks}

Several species possess hydrothecae that resemble, more or less, the shape of those of $S$. tronconica sp. nov., but the latter may be reliably distinguished from its congeners as follows: 1-2) in both S. anguina and S. bipectinata the length/width ratio of the hydrotheca is comparatively higher (Vervoort 1993); 3) the hydrothecae of $S$. inconstans Billard, 1919 are adnate for a greater extent of their adaxial wall (Rees \& Vervoort 1987), and the transverse ridges, which encircle the bodies of proximal hydrothecae, gradually fade off towards the distal end of the colony, and are eventually represented by indistinct undulations of the perisarc on the adaxial side (Billard 1925b); in addition, the internodes are only slightly geniculate and do not reach the degree of geniculation encountered in S. tronconica sp. nov.; 4) S. keiensis Billard, 1925b, but in this species the hydrothecae are slightly smaller and adnate for a longer extent, their surface varies from wrinkled (Billard 1925b) to smooth (Leloup 1937), and there are four lamellar, internal, submarginal cusps (two latero-adaxial and two latero-abaxial); 5) S. leiocarpoides, but this species has comparatively larger, smooth-walled hydrothecae (compare Fig. 9S-T with 9D-F); 6) although very similar morphologically, the hydrothecae of S. natalensis Millard, 1968 have a length/ width ratio of ca 2.1-2.3 (calculated from Millard 1968, 1975), while those of S. tronconica sp. nov.are comparatively more slender, with a ratio of ca 2.4-2.9; in addition, the ridges are common in younger hydrothecae and may totally disappear in the older ones (Millard 1968); moreover, its gonothecae appear more fusiform, only their distal end is wrinkled, and the aperture is surrounded by 3-4 projections of perisarc (Millard 1975); 7) unlike in the present species, the length/width ratio of the hydrotheca in S. undulitheca Vervoort, 1959 is lower, between 2.1 and 2.3 (calculated from Vervoort 1959), its internodes are comparatively shorter and slightly geniculate, and both the hydro- and gonothecae are wrinkled throughout.

\section{Geographical distribution}

New Caledonia and Norfolk Ridge. 


\section{Sertularella tubulosa sp. nov. urn:Isid:zoobank.org:act:8D56454C-7B2C-451C-BFB2-9C42603F3005}

Fig. 9U-X; Table 6

\section{Diagnosis}

Sertularella with lightly polysiphonic, irregularly and sparsely ramified stems; internodes moderately long, geniculate; hydrothecae exceedingly long, tubular, isodiametric throughout, walls entirely smooth; four small marginal cusps, and four submarginal, intrathecal projections of perisarc. Gonothecae unknown.

\section{Etymology}

The specific name is derived from the Latin tŭbŭlus, $-i$, meaning tube, and describes the shape of the hydrotheca.

\section{Material examined}

\section{Holotype}

BATHUS 3: Stn. DW810, single, sterile, branched stem, $2.6 \mathrm{~cm}$ high, lightly fascicled basally, but devoid of hydrorhiza (MNHN-IK-2012-16591).

\section{Description}

The colony, devoid of hydrorhiza, is composed of a single stem, $2.6 \mathrm{~cm}$ high, giving rise to a side branch towards its middle. Perisarc thick basally, thinning out gradually towards tip of colony. Basal part of stem ahydrothecate, overgrown by a few accessory tubes; upper and longest part divided into regular internodes by oblique constrictions of the perisarc slanting in alternate directions. Internodes moderately long, geniculate, widening distally so as to accommodate a hydrotheca. The single side branch originates laterally from below a stem hydrotheca; first internode comparatively longer than subsequent ones; the latter with same structure as the stem. Hydrothecae angled at $40-45^{\circ}$ with the stem; long, tubular, isodiametric throughout, adnate for about $1 / 4$ their length; free adaxial wall nearly straight and smooth; abaxial wall basally convex, becoming rapidly straight for most of its length; basal foramen wide; aperture squared in frontal view, with four inconspicuous marginal cusps separated by shallow embayments; four intrathecal, submarginal cusps: two latero-adaxial and two latero-abaxial; margin often renovated in damaged hydrothecae. Gonothecae unknown.

\section{Remarks}

The characteristic tubular shape of the hydrothecae of this species is diagnostic. Tubular, smooth-walled hydrothecae are only encountered in a few congeners that can be distinguished from the new species on the following accounts: 1) the hydrothecae of S. billardi Vervoort, 1993 have a comparatively lower length/width ratio of the hydrothecae (Vervoort 1993); 2) S. exilis Fraser, 1938 has typically curved hydrothecae (Fraser 1938), and the species is minute (Calder et al. 2009); 3) S. vervoorti El Beshbeeshy, 2011 possesses huge hydrothecae, whose length/width ratio is lower than in $S$. tubulosa sp. nov. (El Beshbeeshy 2011); 4) in $S$. whitei the hydrothecae originate at a more acute angle with the axis of internode, are smaller, curve slightly outwards, and the stem internodes are longer and more slender than in the present species (Rees \& Vervoort 1987).

\section{Geographical distribution}

New Caledonia. 
GALEA H.R., Sertulariid hydroids from the tropical western Pacific

Genus Sertularia Linnaeus, 1758

Sertularia tongensis (Stechow, 1919)

Fig. 10E

Sertularella tongensis Stechow, 1919: 89, fig. $\mathrm{f}^{1}-\mathrm{g}^{1}$.

Sertularia tongensis - Galea 2010: 18, fig. 5h-m (synonymy); 2015b: 10, fig. 3s.

\section{Material examined}

MUSORSTOM 9: Stn. CP1265, small colony composed of a few sterile, unbranched stems, up to $1 \mathrm{~cm}$ high (MNHN-IK-2012-16592).

\section{Remarks}

As stated by Galea $(2010,2015 b)$, this species is immediately recognizable, even in sterile condition, through its alternate hydrothecae whose apertures are closed by two opercular flaps pleated along a median line.

\section{Geographical distribution}

Likely circumglobal in temperate to tropical seas (Galea 2015b). The present record is from the Marquesas.

Genus Symplectoscyphus Marktanner-Turneretscher, 1890

Symplectoscyphus effusus Vervoort, 1993

Fig. 10F-H; Table 7

Symplectoscyphus effusus Vervoort, 1993: 253, figs 59, 60a-e.

\section{Material examined}

NORFOLK 1: Stn. DW1712, small colony composed of several stems up to $11 \mathrm{~mm}$ high, mostly fertile (female), on worm tube covered by sand grains (MNHN-IK-2012-16593).

\section{Remarks}

The long, tubular, upwardly-curved hydrothecae, and the transversely ribbed gonothecae with frilled margin, characteristically curving downwards, are diagnostic (Vervoort 1993). In addition, the comparative measurements of this material and of the holotype (see Table 7) leave no doubt about their conspecificity. The gonothecae in the specimen examined have 4-5 prominent ribs, and these are definitely transversely and not spirally arranged, as stated by Vervoort. Two large oocytes or planulae occur in each gonotheca.

\section{Geographical distribution}

New Caledonia (Vervoort 1993), Norfolk Ridge (present material).

Symplectoscyphus fasciculatus nom. nov.

Fig. 10I-L

Symplectoscyphus johnstoni tropicus Vervoort, 1993: 259, figs 61, 62a-d [not S. johnstoni (Gray, 1843)]. non Symplectoscyphus johnstoni tropicus - Vervoort \& Watson 2003: 217, fig. 51f-1. 


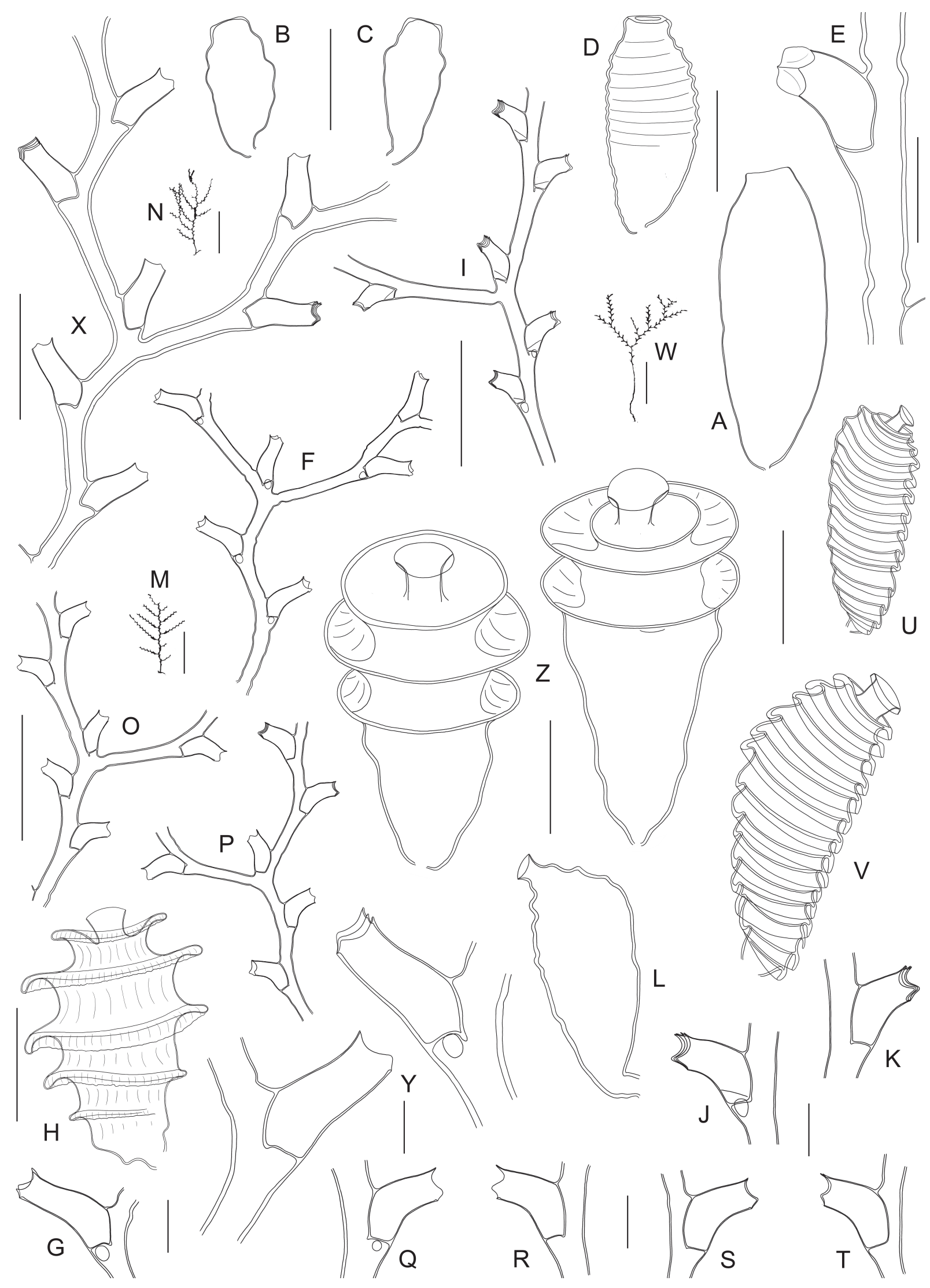


GALEA H.R., Sertulariid hydroids from the tropical western Pacific

Table 7. Measurements (in $\mu \mathrm{m}$ ) of Symplectoscyphus effusus Vervoort, 1993 and S. paucicatillus sp. nov.

\begin{tabular}{|c|c|c|c|}
\hline & \multicolumn{2}{|c|}{ S. effusus Vervoort, 1993} & \multirow{2}{*}{$\begin{array}{c}\text { S. paucicatillus sp. nov. } \\
\text { (present study: BATHUS 4, } \\
\text { Stn. DW923) }\end{array}$} \\
\hline & $\begin{array}{c}\text { Present study: NORFOLK 1, } \\
\text { Stn. DW1712 }\end{array}$ & $\begin{array}{c}\text { Vervoort (1993): } \\
\text { CHALCAL 2, Stn. DW08 }\end{array}$ & \\
\hline \multicolumn{4}{|l|}{ Internodes } \\
\hline - length (in general) & $415-745$ & $405-690$ & $455-875$ \\
\hline - diameter at node & $95-105$ & $65-90$ & $155-230$ \\
\hline \multicolumn{4}{|l|}{ Hydrotheca } \\
\hline - free adaxial side & $305-340$ & $215-235$ & $405-470$ \\
\hline - adnate adaxial side & $150-160$ & $115-170$ & $215-245$ \\
\hline - abcauline side & $325-340$ & $295-320$ & $465-530$ \\
\hline - maximum width & $135-150$ & $105-120$ & $230-250$ \\
\hline - diameter at rim & $130-135$ & $135-140$ & $185-195$ \\
\hline \multicolumn{4}{|l|}{ Gonotheca } \\
\hline - length & ca 1175 & ca 1110 & $1240-1480$ \\
\hline - maximum width & ca 835 & ca 645 & $865-890$ \\
\hline - tube length & - & ca 120 & $165-180$ \\
\hline - tube diameter & - & - & ca 155 \\
\hline - diameter at aperture & ca 175 & ca 110 & $260-270$ \\
\hline
\end{tabular}

non Symplectoscyphus tropicus (Hartlaub, 1901).

\section{Diagnosis}

Symplectoscyphus species of flaccid appearance; stems and side branches fascicled basally, geniculate at origin of branches; branching pseudodichotomous; internodes composed of two alternate hydrothecae and a lateral apophysis with its associated hydrotheca; all hydrothecae tubular, curved outwards; gonothecae sac-shaped, nearly fully adnate, perisarc undulated, aperture round, on top of short funnel.

\section{Etymology}

From the Latin fascis, meaning fascicled, to characterize the polysiphonic habit of the colonies.

Fig. 10. (previous page) - A. Sertularella leiocarpoides Vervoort, 1993 (BATHUS 3, Stn. DW829), gonotheca. - B-C. Sertularella pseudocatena sp. nov. (BATHUS 3, Stn. DW809), two gonothecae. D. Sertularella tronconica sp. nov. (NORFOLK 1, Stn. DW1704), gonotheca. - E. Sertularia tongensis (Stechow, 1919) (MUSORSTOM9, Stn. CP1265), internode with hydrotheca. - F-H. Symplectoscyphus effusus Vervoort, 1993 (NORFOLK 1, Stn. DW1712). F. Portion of colony. G. Hydrotheca. H. Gonotheca. - I-L. Symplectoscyphus fasciculatus nom. nov. (MUSORSTOM 4, Stn. CC174). I. Portion of colony. J-K. Two hydrothecae. L. Male gonotheca. - M-V. Symplectoscyphus ralphae Vervoort, 1993 (NORFOLK 1, Stn. DW1712). M-N. Samples \#1 and \#2, repectively. O-P. Portions from samples \#1 and \#2, respectively. Q-T. Hydrothecae from samples \#1 (Q-R) and \#2 (S-T). $\mathbf{U}-\mathbf{V}$. Gonothecae from samples \#1 and \#2, respectively. - W-Z. Symplectoscyphus paucicatillus sp. nov. (BATHUS 4, Stn. DW923). W. Paratype, colony silhouette. X. Portion of colony. Y. Two hydrothecae. Z. Two gonothecae. Scale bars: A-D, F, I, O-P, X $=1 \mathrm{~mm}$; E $=300 \mu \mathrm{m} ; \mathrm{G}, \mathrm{J}-\mathrm{K}, \mathrm{Q}-\mathrm{T}, \mathrm{Y}=$ $200 \mu \mathrm{m} ; \mathrm{H}, \mathrm{L}, \mathrm{U}-\mathrm{V}, \mathrm{Z}=500 \mu \mathrm{m} ; \mathrm{M}-\mathrm{N}, \mathrm{W}=1 \mathrm{~cm}$. 


\section{Material examined}

Holotype

MUSORSTOM 4: Stn. CP153, "several well developed, flabellate colonies 30×50 mm, stems basally polysiphonic; many appressed gonothecae [...]. One large colony $30 \times 40 \mathrm{~mm}$ is holotype (MNHN-Hy. 1117)" (Vervoort 1993).

\section{Additional material}

MUSORTSOM 4: Stn. CC174, a $4.5 \mathrm{~cm}$ high, fertile (male) colony.

\section{Description}

Flaccid, flabellate, up to $4 \mathrm{~cm}$ high and $5 \mathrm{~cm}$ wide colonies arising from branched, rhizoid stolon. Stems strongly fascicled basally, thinning out gradually to monosiphonic distally; flexuous, usually regularly and alternately branched; occasionally with "irregular" branches resulting from considerable development of secondary stems from branches growing as long as the main stem itself, and resulting in multiple tangled stems, whose distalmost branches form multiple anastomoses between them and with neighboring stems. Division into internodes indistinct, even in monosiphonic parts, but equivalents of internodes long, geniculate, comprising a basal apophysis and its associated axillar hydrotheca, as well as two alternate hydrothecae above. Apophyses alternate. Side branches straight (until they rebranch again in pseudodichotomous manner), nodes indistinct, but each equivalent of internode bearing hydrothecae arranged alternately. Hydrothecae tubular, curving away from internode, adnate for nearly half their length. Free adaxial wall straight to slightly convex; abaxial wall straight basally, curving suddenly in its distal third. Hydrothecal aperture nearly parallel to longitudinal axis of internode; margin with three pointed cusps separated by rather deep embayments; adaxial cusp recurved; renovations common and numerous. No conspicuous submarginal, intrathecal cusps, except for an occasional abaxial thickening. Gonothecae given off from below hydrothecal bases, fitting tightly and neatly against internodes. Male and female similar in shape; sac-shaped, wall undulated and never ribbed; undulations more pronounced distally, fading off basally; aperture distal, borne on outwardly-projecting, trumpet-shaped terminal tube.

\section{Remarks}

The description provided above combines Vervoort's (1993) account with personal observations of the material in hand. The latter apparently belongs to a "large tangled tuft of c. $30 \mathrm{~mm}$ high colonies on wormtubes" previously examined by Vervoort.

Owing to the fasciculate habit of its stems and the gonothecae with undulated walls, the large material studied by Vervoort was assigned to a new subspecies, tropicus, of Symplectoscyphus johnstoni (Gray, 1843). In doing so, Vervoort distinguished it from its congeners with monosiphonic stems and transversely-ribbed gonothecae, viz. S. johnstoni johnstoni (Gray, 1843) and S. johnstoni subtropicus Ralph, 1961, the latter being additionally characterized by the presence of three submarginal, intrathecal cusps.

As stated by Ralph (1961), S. johnstoni is a species with strictly monosiphonic stems, and its gonothecae are provided with " 8 to14 evenly spaced transverse ridges". Consequently, the subspecies tropicus could be confidently raised to species. However, when doing so, it becomes an invalid junior homonym of S. tropicus (Hartlaub, 1901). To avoid this situation, the junior homonym is replaced here with the binomen $S$. fasciculatus nom. nov., whose holotype remains the same for both the original and the new name of the single biological species (ICZN Art. 72.7). The measurements of S. fasciculatus nom. nov. are given by Vervoort (1993: 260, table 51).

A restricted number of species belonging to this highly speciose genus are polysiphonic in habit: six congeners from the Antarctic [S. bellinghauseni Peña Cantero, 2012 (Peña Cantero 2012); 
GALEA H.R., Sertulariid hydroids from the tropical western Pacific

S. cumberlandicus (Jäderholm, 1905) (Peña Cantero et al. 2002); S. frondosus Peña Cantero, 2010 (Peña Cantero 2010); S. hesperides Peña Cantero, 2012 (Peña Cantero 2012); S. liouvillei (Billard, 1914) (Peña Cantero et al. 2002); S. sofiae Peña Cantero et al., 2002 (Peña Cantero et al. 2002)], ten from the subantarctic [S. adpressus (Ritchie, 1911) (Ritchie 1911); S. amoenus Vervoort \& Watson, 2003 (Vervoort \& Watson 2003); S. arboriformis (Marktanner-Turneretscher, 1890) (Millard 1975); S. columnarius (Briggs, 1914) (Ralph 1961); S. divaricatus (Busk, 1852) (Ralph 1961); S. magellanicus (Marktanner-Turneretscher, 1890) (Galea \& Schories 2012); S. patagonicus Galea \& Schories, 2012 (Galea \& Schories 2012); S. paulensis Stechow, 1923 (Watson 2003); S. procerus (Trebilcock, 1928) (Ralph 1961); S. subarticulatus (Coughtrey, 1875) (Millard 1977)], and two from the tropics, both assigned to S. tropicus Hartlaub, 1901 [sensu Clarke 1894 (as Sertularella variabilis) and sensu Billard $1925 \mathrm{~b}]$.

Ecologically, S. fasciculatus nom. nov. occurs in a biogeographical area radically different from that of the majority of species listed above. Its gonothecae are different from those of the following species, which exhibit transverse ridges: S. aggreggatus (Jäderholm, 1917) (Peña Cantero et al. 2002), S. arboriformis (Millard 1975), S. columnarius (Ralph 1961), S. cumberlandicus (Jäderholm 1905), S. magellanicus (Galea \& Schories 2012), S. patagonicus (Galea et al. 2014), S. procerus (Ralph 1961), S. sofiae (Peña Cantero et al. 2002), and S. subarticulatus (Ralph 1961). The gonothecae of S. frondosus (Peña Cantero 2010) and S. liouvillei (Peña Cantero et al. 2002) are exceedingly long and tubular, while those of S. amoenus (Vervoort \& Watson 2003) and S. paulensis (Peña Cantero 2012) are ovoid and have smooth to slightly undulated walls, yet they are not adherent to their corresponding internodes, and their distal tubes are not eccentrically placed. The habit and shape of the gonothecae of $S$. fasciculatus nom. nov. come closest to those of $S$. adpressus. However, the latter is a more robust species, with pinnate appearance, and its hydrothecae are subopposite and highly immersed into their internodes (Ritchie 1911). Although not completely formed in the specimens of $S$. bellinghauseni studied by Peña Cantero (2012), the gonothecae seem "to be characterized by the presence of rings". Similarly, the gonothecae of $S$. hesperides were incipient and apparently smooth (Peña Cantero 2012), but this species is distinguished through its hydrothecae that are adnate for one-third or less their adaxial length. Finally, the gonothecae of $S$. divaricatus are unknown yet, but this species possesses rather highly immersed hydrothecae (Ralph 1961).

\section{Geographical distribution}

New Caledonia (Vervoort 1993).

Symplectoscyphus ralphae Vervoort, 1993

Fig. 10M-V

Symplectoscyphus ralphae Vervoort, 1993: 270, figs 65e-f, 66a-c.

\section{Material examined}

NORFOLK 1: Stn. DW1712, two fertile colonies, ca $18 \mathrm{~mm}$ high, both detached from substrate (sample A) (MNHN-IK-2012-16594); two colonies, 10 and $20 \mathrm{~mm}$ high, the largest bearing two gonothecae (sample B), on bryozoan (MNHN-IK-2012-16595).

\section{Remarks}

The trophosomes of both samples are indistinguishable morphologically (compare Figs $10 \mathrm{M}$ and $10 \mathrm{~N}$; $10 \mathrm{O}$ and $10 \mathrm{P} ; 10 \mathrm{Q}-\mathrm{R}$ and $10 \mathrm{~S}-\mathrm{T}$ ), but the gonothecae they bear are different. Those in sample $\mathrm{A}$ are smaller, provided with 12-14 transverse ridges and a narrow, trumpet-shaped distal tube (Fig. 10U), while those in sample B are comparatively larger, exhibit about 15 ridges, and their distal tube is much wider and has an everted rim (Fig. 10V). Although the gonothecal content in sample A could not be 
confidently ascertained, it may prove to be male; that in sample B contains two large ovoid bodies (either oocytes or developing planulas), and is consequently assigned to the female sex.

Vervoort (1993) did not compare his new species with its congeners, and the present identifications are mainly based on the shape of the gonotheca. However, other symplectoscyphid hydroids belonging to the present collection, but not included in this study, exhibit indistinguishable trophosomes, but their gonothecae are of different sizes and bear a varied number of transverse ridges. Consequently, it is felt that the discrimination of species belonging to certain morphologically related groups of Symplectoscyphus is not possible in the absence of molecular studies, owing to the absence of reliable morphological characters.

\section{Geographical distribution}

New Caledonia (Vervoort 1993), Norfolk Ridge (present study).

Symplectoscyphus paucicatillus sp. nov. urn:1sid:zoobank.org:act:B00A7B9A-265C-48D9-BDDB-71DB49EA7DE7

Fig. 10W-Z; Table 7

\section{Diagnosis}

Symplectoscyphus with monosiphonic stems; branching pseudodichotomous, occurring at irregular intervals; internodes moderately long, slender, geniculate; hydrothecae long, tubular, sigmoid in shape; gonothecae transversely ribbed distally, undulated basally, with trumpet-shaped apical tube.

\section{Etymology}

From the Latin words pauci, -ōrum, meaning a few, and cātillus, -i, meaning small dish(es), making reference to the shape of the gonotheca, which resembles several stacked dishes.

\section{Material examined}

\section{Holotype}

BATHUS 4: Stn. DW923, ca $2.8 \mathrm{~cm}$ high colony, bearing 3 fully formed and one incipient gonotheca (MNHN-IK-2012-16596).

\section{Paratypes}

BATHUS 4: Stn. DW923, two sterile colonies 2 and $3 \mathrm{~cm}$ high (MNHN-IK-2012-16597).

\section{Description}

Colonies up to $3 \mathrm{~cm}$ high arising from creeping, branching hydrorhiza. Stems monosiphonic throughout, composed of a long (up to $1.4 \mathrm{~cm}$ ), lower, ahydrothecate part, and an upper and longest part bearing hydrothecae. Perisarc rather thick and straw colored, thinning out gradually towards tips of colonies; basally a little tortuous, rapidly becoming straight and smooth. Hydrothecate part divided into rather poorly indicated internodes by means of oblique constrictions of the perisarc slanting in alternate directions; each internode moderately long, slender, distinctly geniculate, bearing a hydrotheca distally. Branching pattern pseudodichotomous; side branches arising at irregular intervals from slightly below a hydrotheca, the latter becoming axillar (Fig. 10X); structure identical to that of stem; first internode not significantly longer compared to subsequent ones; up to $2^{\text {nd }}$ order side branches, and all in roughly one plane, giving the colony a flabellate appearance. Hydrothecae originating at very acute angles with the axis of corresponding internode; long, tubular, slightly sigmoid (facing outward basally and upwards distally); adaxial wall adnate for about $1 / 3$ its length; aperture with three pointed, triangular cusps separated by moderately deep embayments; adaxial cusp produced adaxially; opercular apparatus 
GALEA H.R., Sertulariid hydroids from the tropical western Pacific

usually lost; renovation of margin common. Gonothecae borne on both the main stem and side branches, arising usually from below the hydrothecal bases, occasionally from the axil formed by free adaxial wall with next internode; body elongated ovoid, provided distally with 2-3 broad, conspicuous, transverse ribs, and undulated basally, where it tapers to an indistinct pedicel; apical part a flattened plateau from the center of which arises a short trumpet-shaped tube; sex of gonothecae apparently female, judging from the remains of soft tissues (presence of a spherical body, likely an oocyte).

\section{Remarks}

The hydrothecae of this species resemble those of other congeners, but there are points of difference which allow their specific separation, as follows: 1) S. amoenus Vervoort \&Watson, 2003 is a species with fascicled stems, its hydrothecae are deeper (755-920 $\mu \mathrm{m}$, compared to 590-625 in the present material), and its gonothecae have undulated walls (Vervoort \& Watson 2003); 2) S. amphoriferus (Allman, 1877) has comparatively slender hydrothecae (judging from the size of their apertures), and its gonothecae are pear-shaped, with "eleven raised transverse ridges and a slender terminal neck" (Millard 1977); 3) S. effusus Vervoort , 1993, but this is a comparatively smaller species (compare Fig. 10G and 10Y); 4) S. macrocarpus (Billard, 1918), has more slender [according to the size of their apertures (see Billard 1925b; Schuchert 2003)] and shorter hydrothecae (420-470 $\mu \mathrm{m})$; in addition, its gonothecae (of both sexes) are characteristically amphora-shaped (Billard 1925b); 5) S. pedunculatus (Billard, 1919) has longer, more slender, and less adnate hydrothecae (Billard 1925b; Vervoort 1993).

\section{Geographical distribution}

New Caledonia.

\section{Discussion}

Large collections of hydroids originating from the tropical western Pacific were obtained during various expeditions of the French Tropical Deep-Sea Benthos program. Their study, entrusted to various experts, yielded a number of reports dealing with several families of thecate hydroids (see Introduction).

The present work, focusing on hydroids of the family Sertulariidae Lamouroux, 1812, is a continuation of the large account published by Vervoort (1993) and the recent study by Galea (2015), who introduced three new genera, viz. Gonaxia, and Caledoniana and Solenoscyphus, respectively.

In addition to the genera Abietinaria Kirchenpauer, 1884, Caminothujaria von Campenhausen, 1896, Dictyocladium Allman, 1888, Dynamena Lamouroux, 1812, Geminella Billard, 1925b, Hydrallmania Hincks, 1968, Idiellana Cotton \& Godfrey, 1942, Sertularella Gray, 1848, and Symplectoscyphus Marktanner-Turneretscher, 1890 dealt with by Vervoort, members of three other genera, viz. Diphasia L. Agassiz, 1862, Salacia Lamouroux, 1816, and Sertularia Linnaeus, 1758, are discussed herein.

Of the forty-three species, belonging to ten genera, dealt with in the present report, 9 are new to Science, and a subspecies is raised to full species level, accompanied by a name change. Of these, two new species of Gonaxia, added to the 21 congeners described earlier by Vervoort, raise their number to 23 within the study area. Six and two species are added to the widely distributed and speciose genera Sertularella and Symplectoscyphus, respectively. Additional hydroids, partly discussed earlier by Vervoort, also occur in the present collection, and additional notes on their morphology are provided. Finally, other hydroids, such as the poorly known Diphasia cristata Billard, 1920 and Salacia macer Vervoort \& Watson, 2003, occurred as fertile colonies, allowing descriptions of their hitherto unknown gonothecae.

As already underlined by Vervoort for the family Sertulariidae, but also by Peña Cantero \& Vervoort (2010) for the species of Acryptolaria Norman, 1875 (family Lafoeidae Hincks, 1868), the deep-water 
species composition in the study area reveals a high degree of endemism. Regarding the sertulariid hydroids, this is especially true with respect to the genera Caledoniana, Gonaxia, Sertularella and Solenoscyphus. Among the main factors involved, the lack of a free-swimming dispersive stage (Peña Cantero \& Vervoort 2010) limits the capabilities of an efficient dispersal, causing a marked reproductive isolation and, consequently, a high degree of speciation.

Although the hydroid fauna of the study area can be considered as relatively well investigated, it is likely that, with future sampling, new genera and species will be discovered.

\section{Acknowledgements}

Thanks are due to Philippe Bouchet and Pierre Lozouet, both of MNHN, for giving me access to the material described in this paper, and to Aude Andouche for curatorial assistance. The acknowledgements to cruises senior scientists, collectors, captains and crew in Bouchet et al. (2008) also apply here. I am grateful to Dr. Dale Calder (Royal Ontario Museum, Toronto, Canada) for his helpful advice on ICZN matters. Sincere thanks are due to Drs Peter Schuchert (MHNG, Switzerland) and Henry H.C. Choong (Fairbanks Museum \& Planetarium, USA) for constructive comments on an earlier version of this report. This study was undertaken with no financial support.

\section{References}

Allman G.J. 1885. Description of Australian, Cape, and other Hydroida, mostly new, from the collection of Miss H. Gatty. Journal of the Linnean Society of London, Zoology 19: 132-161. http://dx.doi. org/10.1111/j.1096-3642.1885.tb01994.x

Allman G.J. 1888. Report on the Hydroida dredged by H.M.S. Challenger during the years 1873-76. Part II. - The Tubularinae, Corymorphinae, Campanularinae, Sertularinae and Thalamophora. Report on the Scientific Results of the Voyage of H.M.S. Challenger during the year 1873-76, Zoology 23 (70): 1-90. Available from http://biodiversitylibrary.org/page/49519881 [accessed 29 Jun. 2016]

Ansín Agís J., Vervoort W. \& Ramil F. 2009. Hydroids of the family Halopterididae (Cnidaria, Hydrozoa) collected in the western Pacific by various French expeditions. Zoosystema 31: 33-61. http://dx.doi. org/10.5252/z2009n1a3

Bale W.M. 1884. Catalogue of the Australian Hydroid Zoophytes. Australian Museum, Sydney. http:// dx.doi.org/10.1080/00222938509459871

Ansín Agís J., Vervoort W. \& Ramil F. 2014. Hydroids of the families Kirchenpaueriidae Stechow, 1921 and Plumulariidae McCrady, 1859 (Cnidaria, Hydrozoa) collected in the Western Pacific Ocean by various French Expeditions. Zoosystema 36: 789-840. http://dx.doi.org/10.5252/z2014n4a6

Billard A. 1905. Hydroïdes récoltés par M. Seurat aux îles Gambier. Bulletin du Muséum d'Histoire Naturelle, Paris 11: 331-335.

Billard A. 1919. Note sur quelques espèces nouvelles de Sertularella de l'expédition du "Siboga". Archives de Zoologie Expérimentale et Générale 58: 18-23. Available from http://biodiversitylibrary. org/page/6316200 [accessed 12 Jul. 2016]

Billard A. 1920. Note sur quatre espèces nouvelles d'hydroïdes du genre « Diphasia ». Bulletin de la Société Zoologique de France 45: 144-147. Available from http://biodiversitylibrary.org/page/3518646 [accessed 29 Jun. 2016]

Billard A. 1924. Note critique sur divers genres et espèces d'hydroïdes avec la description de trois espèces nouvelles. Revue Suisse de Zoologie 31 (2): 53-74. http://dx.doi.org/10.5962/bhl.part.117788 
GALEA H.R., Sertulariid hydroids from the tropical western Pacific

Billard A. 1925a. Note sur quelques espèces la plupart nouvelles de Synthecidés et de Sertularidés du Siboga. Bulletin de la Société Zoologique de France 49 : 646-652.

Billard A. 1925b. Les hydroïdes de l'expédition du Siboga. II. Synthecide et Sertulariidae. SibogaExpeditie 7b: 117-232.

Bouchet P., Héros V., Lozouet P. \& Maestrati P. 2008. A quarter-century of deep-sea malacological exploration in the South and West Pacific: where do we stand? How far to go? In: Héros V., Cowie R.H. \& Bouchet P. (eds) Tropical Deep-Sea Benthos 25: 9-40.

Calder D.R. 1991. Shallow-water hydroids of Bermuda: the Thecatae, exclusive of Plumularioidea. Royal Ontario Museum Life Sciences Contributions 154: 1-140.

Calder D.R., Vervoort W. \& Hochberg F.G. 2009. Lectotype designations of new species of hydroids (Cnidaria, Hydrozoa), described by C.M. Fraser, from Allan Hancock Pacific and Caribbean Sea Expeditions. Zoologische Mededelingen 83 (32): 919-1058.

Calder D.R., Mallinson J.J., Collins K. \& Hickman C.P. 2003. Additions to the hydroids (Cnidaria) of the Galapagos, with a list of species reported from the islands. Journal of Natural History 37: 11731218. http://dx.doi.org/10.1080/00222930110116039

Clarke S.F. 1894. The hydroids. In: Reports of the dredging operations off the west coast of Central America to the Galapagos, to the west coast of Mexico, and in the Gulf of California, in charge of Alexander Agassiz, carried on by the U.S. Fish Commission steamer "Albatross", during 1891. Bulletin of the Museum of Comparative Zoology 25: 71-78. Available from http://biodiversitylibrary.org/ page/4179595 [accessed 29 Jun. 2016]

El Beshbeeshy M. 2011. Thecate hydroids from the Patagonian shelf (Coelenterata, Hydrozoa, Thecata). Verhandlungen des Naturwissenschaftlichen Vereins in Hamburg 46: 19-233.

Fraser C.M. 1938. Hydroids of the 1934 Allan Hancock Pacific Expedition. Allan Hancock Pacific Expeditions 4 (1): 1-105. Available from http://biodiversitylibrary.org/page/4678840 [accessed 29 Jun. 2016]

Galea H.R. 2007. Hydroids and hydromedusae (Cnidaria: Hydrozoa) from the fjords region of southern Chile. Zootaxa 1597: 1-116.

Galea H.R. 2008. On a collection of shallow-water hydroids (Cnidaria: Hydrozoa) from Guadeloupe and Les Saintes, French Lesser Antilles. Zootaxa 1878: 1-54.

Galea H.R. 2010. Additional shallow-water thecate hydroids (Cnidaria: Hydrozoa) from Guadeloupe and Les Saintes, French Lesser Antilles. Zootaxa 2570: 1-40.

Galea H.R. 2015a. Two new genera and nine new species of hydroids (Cnidaria: Hydrozoa) from off New Caledonia. European Journal of Taxonomy 135: 1-19. http://dx.doi.org/10.5852/ejt.2015.135

Galea H.R. 2015b. Hydroids (Cnidaria: Hydrozoa) from Tristan da Cunha and St. Helena. Marine Biodiversity Records 8 (e154): 1-18. http://dx.doi.org/10.1017/S1755267215001256

Galea H.R. \& Schories D. 2012. Some hydrozoans (Cnidaria) from Central Chile and the Strait of Magellan. Zootaxa 3296: 19-67.

Galea H.R., Schories D., Försterra G. \& Häussermann V. 2014. New species and new records of hydroids (Cnidaria : Hydrozoa) from Chile. Zootaxa 3852 (1): 1-50. http://dx.doi.org/10.11646/zootaxa.3852.1.1

Gibbons M.J. \& Ryland J.S. 1989. Intertidal and shallow water hydroids from Fiji. I. Athecata to Sertulariidae. Memoirs of the Queensland Museum 27 (2): 377-432. 
Hartlaub C. 1901. Revision der Sertularella-Arten. Abhandlungen aus dem Gebiete der Naturwissenschaften, Hamburg 16 (2)(1): 1-143.

Hirohito, Emperor of Japan. 1983. Hydroids from Izu Ôshima and Niijima. Publications of the Biological Laboratory: 1-83, Imperial Household, Tokyo.

Hirohito, Emperor of Japan. 1995. The Hydroids of Sagami Bay. II. Thecata. Publications of the Biological Laboratory: 1-244, Imperial Household, Tokyo.

Jäderholm E. 1896. Ueber aussereuropäische Hydroiden des Zoologischen Museums der Universität Uppsala. Bihang till Kongliga Svenska Vetenskaps-Akademiens Handlingar 21 (4)(6): 1-20. Available from http://biodiversitylibrary.org/page/13457838 [accessed 29 Jun. 2016]

Jäderholm E. 1905. Hydroiden aus antarktischen und subantarktischen Meeren gesammelt von der schwedischen Südpolar-Expedition. Wissenschaftliche Ergebnisse der Schwedischen SüdpolarExpedition 1901-1903 5 (8): 1-41. Available from http://biodiversitylibrary.org/page/6302974 [accessed 29 Jun. 2016]

Jarvis F.E. 1922. The hydroids from the Chagos, Seychelles and other islands and from the coasts of British East Africa and Zanzibar. In: Reports of the Percy Sladen Trust Expedition to the Indian Ocean in 1905, under the leadership of Mr J. Stanley Gardiner, M.A. Transactions of the Linnean Society of London, Zoology (2) 18 (1): 331-360.

Lamouroux J.V.F. 1816. Histoire des polypiers coralligènes flexibles vulgairement nommés zoophytes. F. Poisson, Caen. http://dx.doi.org/10.5962/bhl.title.11172

Leloup E. 1937. Hydropolypes et scyphopolypes recueillis par C. Dawydoff sur les côtes de l'Indochine française. Mémoires du Musée royal d'Histoire naturelle de Belgique (2) 12: 1-73.

Leloup E. 1940. Quelques hydropolypes de la baie de Sagami, Japon. (2e note). Bulletin du Musée royal d'Histoire naturelle de Belgique 16 (19): 1-13.

Millard N.A.H. 1964. The Hydrozoa of the south and west coasts of South Africa. Part II. The Lafoeidae, Syntheciidae and Sertulariidae. Annals of the South African Museum 48 (1): 1-56.

Millard N.A.H. 1968. South African hydroids from Dr. Th. Mortensen's Java-South Africa expedition, 1929-1930. Videnskabelige Meddelelser fra Dansk Naturhistorisk Forening 131: 251-288.

Millard N.A.H. 1975. Monograph on the Hydroida of southern Africa. Annals of the South African Museum 68: 1-513.

Millard N.A.H. 1977. Hydroids from the Kerguelen and Crozet shelves, collected by the cruise MD.03 of the Marion-Dufresne. Annals of the South African Museum 73 (1): 1-47.

Naumov D.V. 1969. Hydroids and Hydromedusae of the USSR. Israel program for scientific translation: 1-631, Keter Publishing House, Jerusalem.

Nutting C.C. 1904. American hydroids. Part II. The Sertularidae. Special Bulletin of the United States National Museum 4 (2): 1-325. Available from http://biodiversitylibrary.org/page/1050964 [accessed 6 Jul. 2016]

Peña Cantero A.L. 2010. On a new species of Symplectoscyphus Marktanner-Turneretscher, 1890 (Cnidaria, Hydrozoa, Sertulariidae), with an annotated checklist of the Antarctic species. Zootaxa 2494: $29-44$.

Peña Cantero A.L. 2012. Filling biodiversity gaps: benthic hydroids from the Bellinghausen Sea (Antarctica). Polar Biology 35 (6): 851-865. http://dx.doi.org/10.1007/s00300-011-1130-y 
GALEA H.R., Sertulariid hydroids from the tropical western Pacific

Peña Cantero A.L. \& Vervoort W. 2010. Species of Acryptolaria Norman, 1875 (Cnidaria, Hydrozoa, Lafoeidae) collected in the Western Pacific by various French expeditions, with the descriptions of nineteen new species. Zoosystema 32: 267-332. http://dx.doi.org/10.5252/z2010n2a5

Peña Cantero A.L., Svoboda A. \& Vervoort W. 2002. Species of Symplectoscyphus MarktannerTurneretscher, 1890 (Cnidaria: Hydrozoa, Sertulariidae) from recent Antarctic expeditions with R.V. Polarstern, with the description of four new species. Journal of Natural History 36: 1509-1568. http:// dx.doi.org/10.1080/00222930110051716

Precker M. \& Lawn I.D. 2010. Hydroids (Cnidaria: Hydrozoa: Leptolida) from Moreton Bay, Queensland, and adjacent regions: a preliminary survey. In: Davie P.J.F. \& Philips J.A. (eds) Proceedings of the Thirteenth International Marine Biological Workshop, The Marine Fauna and Flora of Moreton Bay, Queensland. Memoirs of the Queensland Museum, Nature 54 (3): 109-149, Queensland Museum, South Brisbane.

Ralph P.M. 1961. New Zealand thecate hydroids. Part III. Family Sertulariidae. Transactions of the Royal Society of New Zealand 88 (4): 749-838.

Redier L. 1966. Hydraires et bryozoaires. In: Contribution à l'étude des rivages coralliens d'après les récoltes de Yves Plessis, en Océanie (Mission Singer-Polignac). Cahiers du Pacifique 9: 78-122.

Rees W.J. \& Vervoort W. 1987. Hydroids from the John Murray Expedition to the Indian Ocean, with revisory notes on Hydrodendron, Abietinella, Cryptolaria and Zygophylax (Cnidaria: Hydrozoa). Zoologische Verhandelingen 237: 1-209.

Rho B.J. \& Chang S.R. 1974. On the classification and the distribution of marine benthic animals in Korea. I. Hydroids. Journal of Korean Research Institute for Better Living 12: 133-158.

Ritchie J. 1911. Hydrozoa (hydroid zoophytes and Stylasterina). Memoirs of the Australian Museum 4 (16): 807-869, Australian Museum, Sydney.Available from http://biodiversitylibrary.org/page/35533946 [accessed 29 Jun. 2016]

Schuchert P. 2003. Hydroids (Cnidaria, Hydrozoa) of the Danish expedition to the Kei Islands. Steenstrupia 27 (2): 137-256.

Schuchert P. 2015. On some hydroids (Cnidaria, Hydrozoa) from the Okinawa Islands, Japan. Revue Suisse de Zoologie 122 (2): 325-370. http://dx.doi.org/10.5281/zenodo.30004

Stechow E. 1919. Zur Kenntnis des Hydroidenfauna des Mittelmeeres, Amerikas und anderer Gebiete, nebst Angaben über einige Kirchenpauer'sche Typen von Plumulariden. Zoologische Jahrbücher 42 (1): $1-172$.

Vannucci M. 1951a. Hydrozoa e Scyphozoa existentes no Instituto Paulista de Oceanografia. Boletim do Instituto Paulista de Oceanogrografia 2 (1) : 69-100.

Vannucci M. 1951b. Distribuição dos Hydrozoa até agora conhecidos nas costas do Brasil. Boletim do Instituto Paulista de Oceanogrografia 2 (1): 105-124.

Vervoort W. 1959. The Hydroida of the tropical west coast of Africa. Atlantide Report 5: 211-332.

Vervoort W. 1993. Cnidaria, Hydrozoa, Hydroida: Hydroids from the western Pacific (Philippines, Indonesia and New Caledonia) I. Sertulariidae (Part 1). In: Crosnier A. (ed.) Résultats des Campagnes MUSORSTOM 11. Mémoires du Muséum national d'Histoire naturelle 158: 89-298, Muséum national d'Histoire naturelle, Paris.

Vervoort W. \& Vasseur P. 1977. Hydroids from French Polynesia with notes on distribution and ecology. Zoologische Verhandelingen 159: 1-98. 
Vervoort W. \& Watson J.E. 2003. The marine fauna of New Zealand: Leptothecata (Cnidaria: Hydrozoa) (thecate hydroids). NIWA Biodiversity Memoir 119: 1-538.

von Campenhausen B. 1896. Hydroiden von Ternate, nach den Sammlungen Prof. W. Kükenthal's. Zoologischer Anzeiger 19 (498): 103-107. Available from http://biodiversitylibrary.org/page/9900737 [accessed 12 Jul. 2016]

Watson J.E. 2003. Deep-water hydroids (Hydrozoa: Leptolida) from Macquarie Island. Memoirs of the Museum of Victoria 60 (2): 151-180.

Manuscript received: 22 January 2016

Manuscript accepted: 21 March 2016

Published on: 2 August 2016

Topic editor: Rudy Jocqué

Desk editor: Kristiaan Hoedemakers

Printed versions of all papers are also deposited in the libraries of the institutes that are members of the EJT consortium: Muséum national d'Histoire naturelle, Paris, France; Botanic Garden Meise, Belgium; Royal Museum for Central Africa, Tervuren, Belgium; Natural History Museum, London, United Kingdom; Royal Belgian Institute of Natural Sciences, Brussels, Belgium; Natural History Museum of Denmark, Copenhagen, Denmark; Naturalis Biodiversity Center, Leiden, the Netherlands. 